\title{
Morphological variation and development in a Northern Norwegian role play register
}

\author{
Bror-Magnus S. Strand (i) \\ UiT - The Arctic University of Norway, Faculty of Humanities, Social Sciences and Education, Department \\ of Language and Culture, Postboks 6050 Langnes, 9037 TROMS $\varnothing$, Norway \\ Email: bror-magnus.s.strand@uit.no
}

(Received 01 December 2019; revised 08 October 2020; accepted 12 October 2020)

\begin{abstract}
This paper investigates the variation in and development of a set of morphological variables in a register known to be used by Norwegian children when engaging in role play. In this register they code-switch to something resembling the standard or Oslo variety for their in-character role utterances. The variation across variables, subjects, and age is demonstrated and discussed, and although most variables are used in the standard variants, their rates vary. A fitted binomial generalised mixed effect analysis on the most frequent variables shows that the rate of standard variants increases significantly as an effect of age.
\end{abstract}

Keywords: Child Language; Register Variation; Morphology; Role Play; Norwegian

\section{Introduction and background ${ }^{1}$}

When children engage in role play, they alternate between different roles and layers of reality, switching between utterances as themselves and as their role character. Children have been found to draw on their linguistic repertoire and use linguistic and paralinguistic reflexes to mark roles and layers of reality in role play (ErvinTripp 1973; Gleason 1973; Auwärter 1986, i.a.), henceforth role play registers (RPR). ${ }^{2}$ In Norway, children code-switch from their native dialect into something resembling Oslo dialect or Standard East Norwegian (henceforth SEN) for their in-character role utterances in role play (Gravir 1983; Larson 1985; Guldal 1997; Kleemann 2013, i.a.). This paper reports a longitudinal multiple case study of function words and morphological features in the RPR of 7 Northern Norwegian 3-4 year olds. More specifically, the study investigates (i) the extent to which the morphology of children's RPR corresponds to SEN, (ii) the rate at which children use the SEN variants, and (iii) the extent to which RPR is a linguistic register that develops over time, rather than sporadic use of emblematic features from SEN that show no development throughout the sampling period. To answer the research questions, both qualitative and quantitative methods are used, including a linear mixed effects model analysis. The findings are indeed that (i) SEN variants are used in the RPR, 
but that (ii) there is a great deal of variation in the rate of SEN in the variables, and (iii) a significant increase in the use of SEN variants over time.

This study brings insights into children's acquisition of socio-linguistic register variation and the ontogenesis of competence in two closely related varieties in the individual.

\subsection{Role play and code-switching}

Children start engaging in role play during or at the end of their third year of life (Fein 1981; Nicolopoulou 2018), and its linguistic reflexes develop around the same time (Söderbergh 1980). What these linguistic reflexes are varies individually and culturally, and they range from paralinguistic features, such as alteration in pitch or voice quality (Auwärter 1986; Vedeler 1987; Andersen 2014 [1990]; ErvinTripp 1991), to code-switching between different languages in bilingual populations (Halmari \& Smith 1994; Green-Väntinen 1996; Guldal 1997; Cromdal \& Aronsson 2000; García-Sánchez 2010; Kleemann 2013). With the exception of the dialect area of the capital city Oslo, children growing up in Norway are reported by the layman to code-switch in their RPR to something resembling the Oslo dialect or Standard East Norwegian.

This can be traced back at least several decades in anecdotal reports (Høigård 1999). ${ }^{3}$ The phenomenon has been reported on in passing in the literature (e.g. Venås 1983; Åm 1989; Mæhlum 1992; Allern 1995; Bugge et al. 2017), and in conversation analytical or sociolinguistic studies of code-switching in role play in a Norwegian setting (Larson 1985; Guldal 1997; Kleemann 2013). The structural features of the RPR of Norwegian children have not been studied, with the exception of an MA dissertation (Eliassen 1998) that we will return to below.

Norwegian children's use of standard variants in their RPR lies at the crossroads of macro- and micro-social processes. On the one hand, the form of the RPR should be expected to be subject to fluctuations due to negotiation and children's agency in the specific play constellations: The RPR is used to mark or index the role characters in play, and it should vary along with changes in choices of roles and play frame. On the other hand, it appears to be a part of an established children's culture or folklore: ${ }^{4}$ RPR with SEN features has been reported from several parts of Norway (Larson 1985; Mæhlum 1992; Bjørlykke 1996; Guldal 1997; Eliassen 1998; Kleemann 2013). Most Norwegian children can thus be said to possess a certain bidialectal competence.

The motivation behind this kind of code-switching has often been attributed to children's need to signal 'otherhood' in the literature (Bjørlykke 1996; Høigård 1999), i.e. to index the child's role personae as distinct from the child's everyday persona(e). ${ }^{5}$ Much of child socialisation happens reciprocally between peers (Harris 1995), in activities such as imaginary play (Aronsson 2011; Goodwin \& Kyratzis 2011), and we can assume that this also holds for the codes used in role play. It is negotiated within the micro-social setting of the play itself. Indeed, Kleemann (2015:193) reports that children adapt the code they use in role play to the (assumed) linguistic competence (in Norwegian/Saami) and/or preference of their playmates. But if the structuring of RPR only happened within the micro-social setting, we would not expect the same directionality towards SEN 
across children and regions. Rather, the peer groups should have converged on a set of forms that may vary depending on combinations of children and instantiation of role play, and which could have been drawn from any variety/language in their repertoire.

We can also assume that features of RPR are transferred across age groups, through siblings and older children in the kindergarten, much in the same way as other parts of children's culture are, such as nursery rhymes and games (e.g. hopscotch). ${ }^{6}$ In summary, there seem to be two possible forces driving normalisation of the RPR, one macro-social and one micro-social. On the one hand, the fact that the phenomenon has been reported repeatedly over such a long time and so geographically spread out within Norway may be an indication of a variety existing as part of (a national) children's culture. On the other hand, there is reason to believe that child socialisation happens reciprocally in interaction.

\subsection{Role play and language acquisition}

A relevant question regarding RPR is its status in relation to the child's native dialect (see Eide \& Åfarli (this issue) and their discussion of register specific syntax). Linguistic change and development, in the individual and/or the language society, involves some kind of variation (Bailey 1973; Hickman et al. 2018). As a linguistic variable transitions from one variant (A) to another (B), it happens incrementally, resulting in a period in which both variants are used alongside each other (AB) at various ratios. To the extent there is an age dependent development in the Norwegian RPR in the individual, it can be expected that its linguistic variables develop in the same way, on top of the register's inherent variability mentioned above. One can then ask whether the 'varieties' - RPR and the child's native dialect - exist as separate linguistic subsystems or 'languages' within the individual, and, if so, at which point in time during the incremental separation the split(s) occur(s). Does every instance of variability include multiple grammars, as in the strongest interpretation of the universal bilingualism hypothesis (Roeper 1999), or are separate linguistic subsystems limited to where the differences lie in language competence and not performance only, in the traditional sense of the dichotomy (Chomsky 1965)?

In second language (L2) acquisition, such an incremental development does not spring to mind. In the normal turn of events of L2 acquisition, equivalent variants (of e.g. lexemes and morphemes) of the L1 and L2 are not used alongside each other, and the claim of separate subsystems becomes immediately reasonable. However, as studies in cross linguistic transfer have shown us, this is obviously not the case for all parts of the linguistic system, and states in which two variants of underlying structures - in the case of structural transfer - or phonological systems - in the case of learner accents - exist alongside each other probably exist (see Eide \& Åfarli (this issue) and their discussion of interlanguages). Thus, although one can not refer to RPR as an L2 in the present case, there are clear similarities, especially in that it is a variant that is acquired in addition to the L1 or native dialect.

If we look away for a second from the structural properties of the different varieties in question to view it from a functional perspective, it is clear that whatever linguistic material is used to index role play has to be cognitively 'indexed' as 
belonging to a specific register: For RPR to be able to mark 'otherhood', the child must be able to identify linguistic features as belonging to RPR or the native dialect, consciously or otherwise. This cognitive indexing of variants into functional subsystems is a clear indicator that the child's native dialect and the child's RPR are two separate subsystems within the child's competence in language, at least functionally. The qualitative ways in which this differs from traditional bilingualism and bi(dia) lectalism is a field of study worthy of further investigation, that I hope this paper can contribute to.

\subsection{Linguistic background}

In the context of Norway and Norwegian, the term 'Standard East Norwegian' deserves further discussion. Although Norwegian has two codified written standards (Nynorsk and Bokmål), these are officially seldom spoken outside of theatre stages and national news broadcasting (Vikør 1993), and as opposed to many other parts of Europe, there is a high acceptance of regional speech variation in all parts of society (Vikør 1993; Kerswill 1994). The diglossic situation often found elsewhere, where speakers code-switch to a standard in certain (formal) situations is not the norm in Norway. Despite this, there are examples of dialect levelling in the direction of SEN, together with regionalisation (Mæhlum 2009, Røyneland 2009, see also Lundquist et al. this issue for examples in the Tromsø dialect). For these reasons, among others, it is a matter of debate whether Norwegian has a standard spoken variety at all (Jahr \& Mæhlum 2009; Bull 2009), and, if so, which one(s) should be regarded as (the) standard (see e.g. Sandøy 2009). A reason for considering Standard East Norwegian the standard spoken variety is that the varieties spoken by socioculturally prestigious groups in the Oslo area strongly resemble the Bokmål written standard, and that this is conceived as a norm ideal (Mæhlum 2009). In any event, the term 'Standard East Norwegian' will be used here (short SEN), and Bokmål orthography and the pronunciation of SEN given in Vanvik $(1985)^{7}$ will function as a proxy.

Although the choice of the term 'Standard East Norwegian' does not in itself represent a stance in the aforementioned debate of whether Norwegian has a spoken standard variety, surely, the use of SEN variants in role play across generations and locations could be used as an argument in that discussion. However, the input source(s) of the RPR is pro tem unknown, and so is the target variety for children's RPR. The choice of SEN as a term, with the proxies mentioned above, is first and foremost pragmatic: It is a spoken variety - as opposed to for instance the written Bokmål standard - and it does not encompass the variation found in South Eastern Norwegian dialects, and even the Oslo dialect. It is used purely as a scaffold for describing the RPR and its variation and development, informed by previous literature, and the RPR, may - but crucially does not need to - be equal to SEN (see also endnote 2).

This paper investigates both free and bound morphemes in the children's role play register, and to what extent they coincide with the SEN variety. In order to do this, it is first necessary to determine how SEN differs from the children's local dialect. The study is situated in Tromsø, a city with approximately 76,000 inhabitants located in Northern Norway. The Tromsø dialect has features share with 
Table 1. Personal and indefinite pronouns and possessive determiners in TTD and SEN (the gloss indicates possessee (p.-ee) and possessor (p.-or) marking, where relevant)

\begin{tabular}{|c|c|c|c|c|}
\hline & Variable & TTD semi- orthographic & SEN orthographic & Gloss \\
\hline \multirow[t]{9}{*}{ Pronouns } & I & $æ$ & jeg & ‘' \\
\hline & ME & $m æ$ & meg & 'me' \\
\hline & YOU.SG & $d æ$ & deg & 'you (sg. obl.) \\
\hline & SHE & ho & hun & 'she' \\
\hline & HER & ho & henne & 'her' \\
\hline & REFL & $s æ$ & seg & 'him-/herself, themselves' \\
\hline & THEY & dem & de & 'they' \\
\hline & THEM & dem & dem & 'them' \\
\hline & YOU.PL & dokker & dere & 'you' (pl.) \\
\hline \multirow[t]{6}{*}{ Possessives } & HIS & hannes & hans & 'his' \\
\hline & OUR & vårres/vårs & vår & 'our' (m./f. p.-ee) \\
\hline & & & vårt & 'our' (n. p.-ee) \\
\hline & & & våre & 'our' (pl. p.-ee) \\
\hline & YOUR & dokkers & deres & 'your' (pl. p.-or) \\
\hline & THEIR & demmes & deres & 'their' \\
\hline \multirow[t]{2}{*}{ Ind. } & SOME & nokken/nån & noen & 'some(one)' \\
\hline & SOMETHING & nokka & noe & 'something' \\
\hline
\end{tabular}

speakers in other Northern Norwegian towns, such as Bodø, Harstad, and Narvik (Bull 1990; Nesse \& Sollid 2010). The differences between SEN and the traditional Tromsø dialect (TTD) as reported in the literature (Iversen 1918; Bull 1990) are summarised in Tables 1 for pronouns and possessives, and 2 for nominal morphology. ${ }^{8}$ As with SEN, TTD is not meant as an accurate description of a variety encompassing its variation, but is used as a point of reference: In conjunct, SEN and TTD are meant to outline the space of variation within which we expect the the children's output to take place.

Starting with the pronouns, there is a great deal of variation in the pronominal systems across Norwegian dialects (Sjekkeland 2005: 106-108). Although about half of the pronouns have the same form in TTD and SEN, and are excluded from the overview in Table $1,{ }^{9}$ there are still a number of pronouns that differ between the varieties, some of which merit further discussion:

First, there is a parallelism in the pronouns I, ME, YOU.SG (i.e. non-subject), and REFL, ${ }^{10}$ in that the TTD variants end in a long, open [æ:] ([æ:], [mæ:], [dæ:], and [sæ:], respectively), whereas the SEN variants end in a diphtong [æi] ([jæi], [mæi], [dæi], and [sæi], respectively). Second, the use of number/gender and case marking is unevenly distributed between the varieties. For instance, TTD, but not SEN, has 
Table 2. Nominal inflection (inflected for definiteness ((in)definite) and number (singular/plural))

\begin{tabular}{|c|c|c|c|c|c|c|}
\hline & & TTD Indef. & Def. & SEN Indef. & Def. & gloss \\
\hline \multirow[t]{4}{*}{$\mathrm{m}}$. & sg. & bil & bilen & bil & bilen & (the) car \\
\hline & pl. & bila & bilan & biler & bilene & (the) cars \\
\hline & sg. & mann & mannen & mann & mannen & (the) man \\
\hline & pl. & menn/manna & mennern & menn & mennene & (the) men \\
\hline \multirow[t]{4}{*}{ f. } & sg. & geit & geita & geit & geita & (the) goat \\
\hline & pl. & geite & geiten & geiter & geitene & (the) goats \\
\hline & sg. & bok & boka & bok & boka & (the) book \\
\hline & pl. & bøker & bøkern & bøker & bøkene & (the) books \\
\hline \multirow[t]{3}{*}{$n}$. & sg. & tak & taket & tak & taket & (the) roof \\
\hline & pl. & tak & takan & tak & takene/taka & (the) roofs \\
\hline & & $' \mathrm{~N}(\mathrm{~s})$ ' & 'the $N(s)$ ' & $' \mathrm{~N}(\mathrm{~s})$ ' & 'the $\mathrm{N}(\mathrm{s})$ ' & \\
\hline
\end{tabular}

syncretism in SHE/HER, ${ }^{11}$ THEY/THEM, ${ }^{12}$ and the number/gender agreement in OUR. ${ }^{13}$

Finally, two indefinite pronouns or determiners, SOMETHING and SOME, have been included in the analysis. ${ }^{14}$

There are two differences between the two variants of the present tense form of copular 'be' (orthographically er, henceforth BE). First, the SEN variant has a word final $/ r /$, which is absent in TTD. Second, there is a difference in vowel quality between the two, where SEN has a saliently more open vowel ([æ: $]$ ), than the TTD variant ([e:]). Since word final $/ \mathrm{r} / \mathrm{s}$ in SEN often are elided in certain contexts (i.a. before labial and velar consonants), in addition to the fact that $/ \mathrm{r} /$ is a consonant mastered late by Norwegian children (Tetzchner, Stephen von et al. 1993: 114), for every case, the vowel quality is the main diagnostic to determine the variant used in this study.

Lastly, nominal inflection (given in Table 2) differs in the two varieties both in the form of the form of the inflectional suffixes, but also in that TTD has different declension classes for masculine and feminine also in plural forms for the nonumlauted paradigms (m:-an, f:-en, versus SEN f/m:-ene).

\subsection{Previous findings}

Although previous research has labeled the variety used as RPR as 'East Norwegian' (e.g. Mæhlum 1992; Bugge et al. 2017), 'Standard' (e.g. Guldal 1997), 'Bokmål' (name of written standard), 'West-side Oslo dialect', or 'Southerner' (Kleemann 2015, my translation), the specific grammatical or phonological features this pertains to are seldom and scarcely discussed. In the cases where the form of the variety is mentioned, pronouns (Guldal 1997) and intonation (Kleemann 2015) are recurring features. In describing RPR Kleemann (2015) also mentions, without 
specifying, lexical and inflectional differences, (over)use of the SEN HER variant henne, also in subject position, and the use of the SEN BE variant er (cf. Section 1.3).

As mentioned above, Eliassen (1998) is the only study in which the focus is primarily on the structural properties of the variety used in Norwegian children's role play register. Based on recordings of spontaneous speech from four children from Meløy in Northern Norway, a rural island almost $400 \mathrm{~km}$ - or a ten hour drive south of Tromsø, Eliassen gives a qualitative overview of the differences between the language used in role utterances and the language used in directing/planning in four different domains: lexicon, morphology, phonology and intonation/prosody (p. 52). At all levels she finds variation. No feature is used consistently in the standard variant, and the rate at which the standard variant is used varies across feature and child. Beginning with the pronouns, all children used the SEN variants of I, ME, YOU.SG, and REFL (to the extent the variables were attested in the material), whereas the SEN variant of SHE and YOU.PL were only attested in two and one of the children respectively, and to a lesser extent than the four other pronouns. In addition, she attested the hybrid form $x i$ of the variable I.

In verb morphology, Eliassen (1998) found instances of suffixed (SEN) variants of strong verbs in all four children. In addition, the children tended to use the long, standard variant of other morphemes as well, instead of the short local version with apocope (a more pronounced dialect feature in southern parts of Northern Norway, and not relevant for the present data). Lastly, of the morphological features, standard versions of plural inflection of nouns were also attested from all children.

Similar to the Tromsø dialect, the Meløy dialect traditionally also has palatalisation of traditional alveolars/dentals and has undergone 'lowering' (cf. endnote 12). Children 'reversed' these sound changes in their role utterances, producing alveolars/dentals and more closed vowels instead.

Eliassen (1998) gives a good first overview of Northern Norwegian Children's RPR. The present study will expand on Eliassen's findings, both by increasing the amount of data and by adding the longitudinal dimension. This makes it possible not only to revisit Eliassen's qualitative findings, but add quantitative and developmental investigations, looking at the actual ratios between SEN and TTD variants in the most frequent variables and across time.

\section{Aim of the study}

This study investigates Northern Norwegian children's use of certain morphological features of SEN, both qualitatively and quantitatively. Given the small number of previous studies of this phenomenon, the present study is necessarily explorative in nature. Therefore, this study sets out to answer the following research questions. For the variables under investigation:

1. To what extent do the children use SEN variants or other variants alien to the local dialect in their RPR?

2. What is the rate at which the SEN (or other) variants are used in RPR?

3. Is there a change or development over time in the extent or consistency that children use these variants in their RPR? 
As mentioned, this paper does not take a stance as to whether there is a Norwegian spoken standard variety. Rather, with the first question this study investigates, qualitatively, the extent to which forms from a postulated variety are used in role utterances by Norwegian children (cf. the discussion in Section 1.3 on SEN and in endnote 2). RPR lies at the crossroads of macro- and micro-social processes which is addressed by research question three. Any influence of RPR as a national children's folklore should be visible through a clear direction towards SEN in the variants used in RPR, across children and over time. The micro-social structuring should be visible through fluctuations in the variants used between constellations of children and instances of role play. These are not mutually exclusive. There can be minor fluctuations while still being an overall direction.

\section{Method}

The present paper reports a longitudinal multiple case study of 7 Northern Norwegian 3-4 year olds. The study uses a corpus of 18 audio-visual recordings of spontaneous play made over the course of approximately one year. The current section gives an overview of the recruitment and recording procedures (Section 3.1) and the procedures for transcription and coding (Section 3.2).

\subsection{Data collection}

The data in this study are based on a series of audiovisual recordings made over a year ( 27 sessions) in a kindergarten in Tromsø, with 13 children ( 8 from session 1 , and an additional 5 from session 16). ${ }^{15} 18$ of these and 7 children were selected for further analysis and transcribed.

The audio recordings were made using a handy recording device (Zoom ${ }^{\oplus} \mathrm{H} 4 \mathrm{n}$ pro) and two condenser microphones (Samson ${ }^{\circledR} \mathrm{C} 02$ ) hanging from the ceiling (sessions 1-19) or the built in microphones in the recording device (from session 20). ${ }^{16}$ With the exception of two recordings, all audio was recorded in stereo WAV Audio format with a sample rate of $44.1 \mathrm{kHz}$. Video recordings were made with a wall mounted camera (GoPro ${ }^{\circledR}$ HERO Session), in MPEG-4 file format and H.264 encoding. ${ }^{17}$ The recording sessions were held between seven and 21 days apart, with the exception of the summer break where there were 49 days between two recordings. The video recordings lasted on average around $1 \mathrm{~h} 20 \mathrm{~min}$. The sessions consisted of placing toys (a doll's house with furniture and a doll family (session 1 and onwards), a fire truck engine and two firefighters, (session 5 and onwards), and a fire station (from session 19)) in a designated room in the kindergarten, and allowing all children for whom parental consent had been obtained to come into the room and play. The researcher and the staff would try to make sure that the room was not too crowded, and a general rule was enforced where a maximum of three children could be in the room at once. This was done in order to achieve a good dynamic in the role play, i.e. that all participated in the same 'game', and to facilitate transcription, i.e. not too many children talking at the same time. As the children were given the freedom to enter and exit the room at will, they were eager and motivated to play, but this also meant that the children were not recorded consistently, 
resulting in differences between the children both in regard to the amount of speech and the number of sessions recorded from each of them.

Five of the children did not participate in the study before recording 16, and one of the original eight children participated in barely any role play during the recording sessions. To ensure comparability between the children, those six were excluded from the study, resulting in the final seven. All the children are monolingual Norwegian, except for Hedda and Inga, who are bilingual English-Norwegian. From the information given by the parents regarding their language background, there is no indication that any of the seven children's parents speak a variety that could be regarded as SEN at home. Recall from Section 1.3 that Norwegian speakers generally use their own dialect in all parts of society, so the parents will not be an input source of SEN, with the possible exception of role play. All the children have been anonymised, and names have been substituted.

\subsection{Transcription and coding}

18 recordings were selected for further analysis based on the composition of children and their relative distance in recording date. There is a higher concentration in the selection in the first half of the period than the second, in the anticipation of a faster development closer to the onset of role play in or towards the end of their third year of life (Fein 1981; Nicolopoulou 2018). The distance in months from the first recording and the children's ages of each recording are given in Appendix A.

The recordings were transcribed in ELAN (Brugman \& Russel 2004). ${ }^{18}$ The transcriptions were made using the transcription standard used in the LIA corpus (see the manual in Hagen et al. 2018), a phonetic transcription based on Norwegian orthography, using the Norwegian alphabet and no diacritics, ensuring both efficiency and fidelity.

Utterances were coded for level of pretence, i.e. everyday utterances, planning utterances (meta comments and 'setting the stage'), magical utterances (onomatapoeia and 'ludic speech acts', see Strömqvist 1981, 1984; Høigård 1999), and role utterances. Utterances were coded as role utterances only if they fulfilled one of the following criteria:

1. The utterance was clearly referring to something not happening in the 'baseline reality' (e.g. 'I am peeing' or 'there's a fire!'), and/or

2. The utterance was uttered with a voice quality or intonation that was clearly manipulated in a creative way as to indicate role utterances, and/or

3. The utterance was uttered while holding and animating a doll, and/or

4. The utterance was uttered as an answer to or in a conversation together with an utterance with the characteristics in 1-3.

In cases where there was doubt, the utterances were coded as undecided.

As with all verbal text, and especially as unmonitored and referentially complex as the type in question here, the researcher's interpretation of the text is always a possible source of error. To nevertheless ensure reproducibility, replication data 


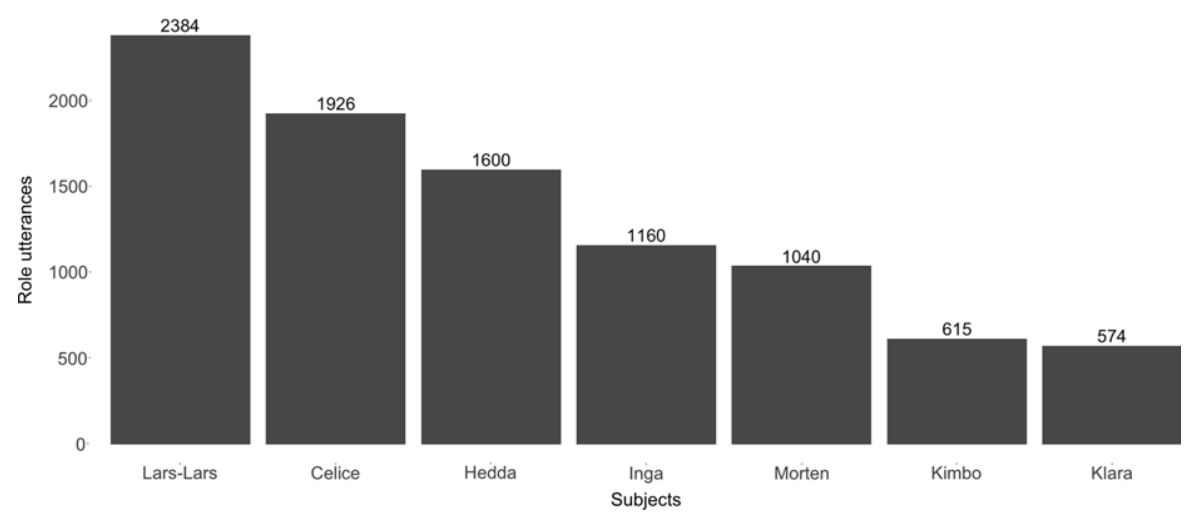

Figure 1. Role utterances per subject.

have been uploaded to The Tromsø Repository of Language and Linguistics (TROLLing). ${ }^{19}$

\section{Results}

This section presents the results of the study, variable by variable (nouns, pronouns, possessive determiners, and copular be (BE)). For each (group of) variable(s), a qualitative overview is first given, where the extent to which the variables under consideration are attested in the SEN (or any other) variant in the data are presented, accompanied by examples from the corpus. This is meant to answer research question 1 and can be seen in comparison to the findings in Eliassen (1998, see Section 1.4).

Secondly, the ratio of SEN to TTD variants is given for each variable, giving us insight into the children's performance and use of the different variables. As we will see, for some variables the SEN variant is used more consistently, whereas others barely are. This answers research question 2 .

Since looking at the collapsed rates of SEN in different variables may give a distorted picture that may cover up individual differences between subjects and/or recordings, thirdly the ratios of SEN to TTD variants are given across time for the variables with more than 126 observations: ${ }^{20}$ I, ME, YOU.SG, YOU.PL, and $\mathrm{BE}$. This should uncover the different kinds of variation and answer research question 3.

Lastly in a separate section, generalised mixed effects model analyses on the two most frequent variables, $\mathrm{I}$ and $\mathrm{BE}$, are given.

The results are based on 9,299 role utterances from the 18 recordings, divided between the seven children as shown in Figure 1.

Throughout, the result from children's RPR will be compared to children's utterances in their native dialect as present in the data (out-of-play or planningutterances, henceforth Children's Tromsø Dialect, CTD).

Before moving on it should be mentioned that no evidence was found of other dialects being used as RPR in the group. 
Table 3. Variants of mann ('man') attested in the material: in the children's out-of-role utterances (CTD) and in children's utterances in role play (RPR). Boldface in CTD indicates divergence from TTD. Boldface in RPR indicates divergence from SEN

\begin{tabular}{|c|c|c|c|c|c|}
\hline & TTD & CTD & RPR & SEN & gloss \\
\hline \multirow[t]{3}{*}{ indef. } & menn/manna & manna & manna & menn & men \\
\hline & & & menner & & \\
\hline & & & manner & & \\
\hline \multirow[t]{4}{*}{ def. } & mennern & mennern & mennene & mennene & the men \\
\hline & & mennene & mennern & & \\
\hline & & mannan & mannan & & \\
\hline & & mennan & mennen & & \\
\hline
\end{tabular}

\subsection{Nominal inflection}

Plural nouns are far from frequent in the material. From the scarce data we have, it seems that children use the SEN variant of both the definite and indefinite plural suffix (see examples (1) and (2)). The most frequent nominal lexeme found in plural was mann ('man'), but always in the compounds brannmann ('fireman') and redningsmann ('saviour', lit. 'saving man'). This is an irregular noun with ablaut (see Table 2 in Section 1.3). As is to be expected from children three years of age, they do not inflect nouns consistently, and seem to overgeneralise the regular masculine paradigm onto this noun. Thus, the only indefinite variant found in CTD, is the overgeneralised manna (the un-ablauted stem mann with the TTD regular masculine indefinite plural ending $-a$ ), which is also attested in children's RPR. In addition, we find examples of the SEN plural ending -er in this noun, with or without an ablauted stem, giving the three variants mann-er, menn-er, and manna (see Table 3). We find no examples of the SEN/TTD variant menn in either register.

In the plural definite variant, four variants are found in CTD; mennern (the TTD variant), one instance of mennene (the SEN variant), mannan, and mennan (the TTD regular masculine definite plural ending on an un-ablauted and ablauted stem respectively). In the children's RPR, we also find mennene (SEN), mennern (TTD), mannan, and a variant with ablaut but without the retroflex ending, mennen. What we can take away from this is that the children seem to relate the SEN suffix -er as a RPR variant, applying it to nouns to mark role play, albeit sometimes incorrectly.

(1) a. vil du ha mere pannekake-r lillesøster? will you have more pancake-PL little.sister?

((3)Morten, 3;4) 'do you want more pancakes little sister?'

b. jeg har tatt på skøyte-r

I have taken on ice.skate-PL

((15)Hedda, 3;6)

'I have put on ice skates'

c. $æ$ har mange kaffe-r i kjøleskapet mitt ((21)Kimbo, 3;7)

I have many coffee-PL in refrigerator my

'I have many coffees in my refrigerator' 
(2) a. her e stig-ene

((5)Selfridia, 3;1)

here is.TTD ladder-PL.DEF

'here are the ladders'

b. va det kke fint hos brannmenn-ene?

((27)Lars-Lars, 3;8)

was it not nice at firefighter.PL.DEF

'wasn't it nice at the firefighters' place?'

Unfortunately, the infrequency and inconsistency of plural forms in the corpus cuts the presentation of the nominal results short here, without any quantitative ratio analysis.

\subsection{Pronouns and possessive determiners}

Starting with the qualitative overview, all pronouns were attested in their TTD variant, and all, except HER, were attested in their SEN variant in RPR (see Table 4). Examples of some of the pronouns used in their SEN variant (I, ME, YOU.SG, SHE, YOU.PL, THEY, SOME, and SOMETHING) are given in (3).

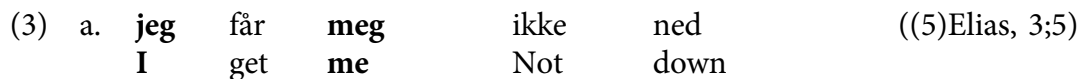
'I can't get myself down'

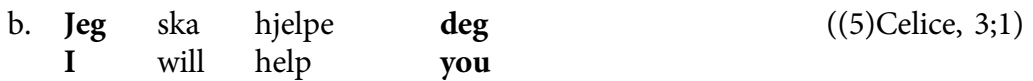

c. hun har så veldig vondt i kneet ((9)Celice, 3;2) she has so very pain in knee.def

'her knee is hurting so very badly'

d. han må skamme seg he must be.ashamed him.self

((16)Celice, 3;6)

'he should be ashamed of himself I have something to.PREP to.INF say you.PL

'I have something to tell you'

f. de faller ned

((14)Hedda, 3;6)

they fall down

'they are falling down'

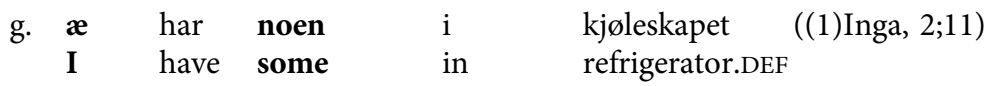

'I have some in the refrigerator'

h. er det noen her? ((7)Celice, 3;2)

is it someone here?

'is there someone here?'

i. okay \# da ska jeg hente noe ((9)Hedda, 3;4)

okay \# then will I bring something

'then I will go and get something' 
Table 4. Overview of pronouns in the material: in the children's out-of-role utterances (CTD) and in children utterances in role play (RPR). Boldface in CTD indicate divergence from TTD. Boldface in RPR indicate divergence from SEN. N marks the number of role utterances with any variant of the variables

\begin{tabular}{|c|c|c|c|c|c|c|c|}
\hline & Variable & TTD & CTD & RPR & SEN & Gloss & In $\mathrm{N}$ role utterances \\
\hline \multirow[t]{9}{*}{ Pronouns } & I & $æ$ & $æ$ & jeg/[æi] & jeg & ‘’ & 2,805 \\
\hline & ME & $m æ$ & $m æ$ & meg & meg & 'me' & 354 \\
\hline & YOU.SG & $d æ$ & $d æ$ & deg & deg & 'you' (sg. obl.) & 239 \\
\hline & SHE & ho & ho & hun (henne) & hun & 'she' & 58 \\
\hline & HER & & & ho (hun) & henne & ‘her’ (obl.) & 18 \\
\hline & REFL & $s æ$ & $s æ$ & seg & seg & '-self' (3rd) & 13 \\
\hline & THEY & dem & dem/de & de & de & 'they' & 34 \\
\hline & THEM & & & dem (de) & dem & 'them' & 13 \\
\hline & YOU.PL & dokker & dokker & dere & dere & 'you' (pl.) & 181 \\
\hline \multirow[t]{6}{*}{ Possessives } & HIS & hannes & hannes & hannes & hans & 'his' & 1 \\
\hline & OUR & vårres/vårs & vårres & vår & vår & 'our' (m./f.) & 34 \\
\hline & & & & vårt & vårt & 'our' (n.) & 27 \\
\hline & & & & vårres & våre & 'our’ (pl.) & 2 \\
\hline & YOUR & dokkers & dokkers & deres & deres & 'your' & 19 \\
\hline & THEIR & demmes & demmes & demmes & deres & 'their' & 3 \\
\hline \multirow[t]{2}{*}{ Ind. } & SOME & nokken/nån & nån/noen & noen & noen & 'some(one)' & 40 \\
\hline & SOMETHING & nokka & nokka/noe & noe & noe & 'something' & 50 \\
\hline
\end{tabular}


For some pronoun variables, the SEN variant is also attested in the Tromsø dialect of the children (CTD): THEY, SOME, and SOMETHING. The situation is more complex with THEY since SEN marks subject and oblique arguments differently (de and dem respectively). This is not the case for CTD, where de and dem are used for subjects and oblique arguments in seemingly free variation (examples (4) and (4), from out-of-play utterances). This also holds for the RPR, where de is also attested in oblique arguments (examples (6)).

(4)
a. æ e ferdig med de
I am done with they
'I am done with them'
b. no har $\boldsymbol{x}$ de [Inga] ((5)Celice, 3;1)
now have I they I.
((2)Inga 2;11)
'I have them now, Inga'

(5) a. korfor tok dem av den? ((5)Inga 3;1)

why took them off that.one?

'why did they take that one off?'
b. si at dem e slem ((21)Lars-Lars, 3;8)
say.IMP that them are mean
'tell them that they are mean!'

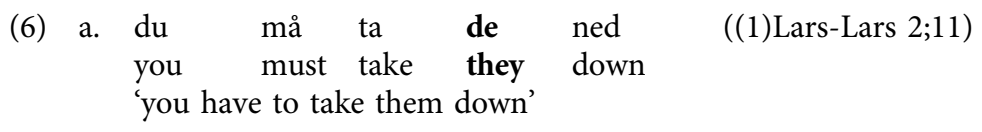

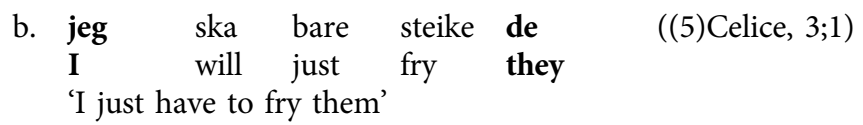

As mentioned, there are no instances of the SEN variant of HER (henne) in nonsubject position in the data. Instead, the TTD variant or the SEN variant of SHE was used. The children varied between the TTD and the SEN variant of SHE in contexts where HER would be expected (examples (7)). ${ }^{21}$ In addition, there are two examples of the SEN HER variant henne used in subject positions, both from Kimbo in file 14 (as reported by Kleemann 2015, see endnote 11).
(7) a. jeg hjelpa ho
I *helped her
'I helped her'
b. jeg sir bra te ho $\quad((5)$ Celice, $3 ; 1)$
I say good to her
'I say 'good' to her'
((9)Lars-Lars, 3;2)

(8) a. henne må inn i brannbil ((14)Kimbo 3;3)

her must in in fire.engine

'she has to go inside the fire engine' 

b. henne må jo også være... her must well also be...
'she also has to be...'
((14)Kimbo, 3;3)

We also find instances of an intermediate variant [æI] of I:
a. [æI] skyta deg
I *shot you
'I shot you'
b. [æI] så brann Her I saw fire here
'I saw fire here'
((14)Celice, 3;4)
((7)Morten 3;5)

Moving on to the possessive determiners, there are no instances of the SEN variant of the variables HIS, THEIR, and the plural agreeing form of OUR. These variables are however barely attested in RPR in the present study (once, thrice, and twice respectively, see Table 4). Both masculine/feminine and neuter agreeing forms of OUR are attested in the SEN variant (examples (10a) and (10b)) as well as YOUR (10c), which are also much more frequent in the data.

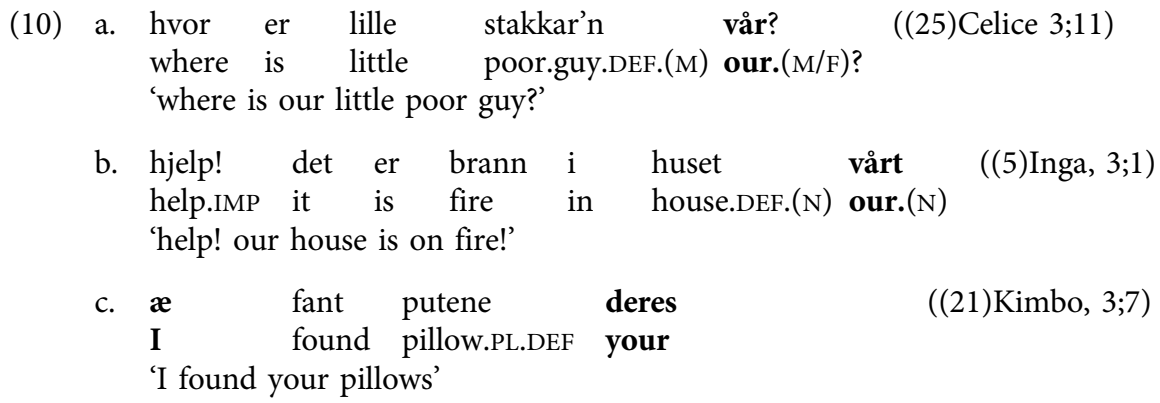

In summary, the children in the current study use the SEN variants of all pronouns, with the exception of HER. For the sufficiently attested variants in the possessive determiners, children use the SEN variant of these as well. This is in concordance with the findings in Eliassen (1998), except that SEN variants are attested in even more variables here. This is probably related to the amount of data available.

Before looking at the rate of SEN in pronouns and possessive determiners in the children's RPR, it would be useful to gauge the relevant quantitative variation existing in CTD for some of the more frequent pronouns where this is relevant (Table 5). As mentioned above, the pronominal system seems to be undergoing some levelling in some of the variables, in particular THEY, THEM, SOME, and SOMETHING. This is evident in Table 5, where THEY, SOME and SOMETHING are used in the SEN variant $68.9 \%, 43.5 \%$, and $10.4 \%$ respectively. In addition, the SEN variant of THEY, $d e$, are used in $60 \%$ of the places where THEM (dem) would traditionally be expected, being indicative of the seemingly free variation between the two in CTD mentioned and exemplified above. A search in a speech corpus (Nordic Dialect Corpus, Johannessen et al. 2009) also bolsters this suspicion: Among young 
Table 5. Rates of SEN variants in pronouns in CTD

\begin{tabular}{lclclc}
\hline Variable & SEN(\%) & Variable & SEN(\%) & Variable & SEN(\%) \\
\hline I & $1.4 \%$ & SHE & $2.9 \%$ & THEY & $68.9 \%$ \\
\hline ME & $1.3 \%$ & HER & $0 \%$ & SOME & $43.5 \%$ \\
\hline YOU.SG & $4.9 \%$ & YOU.PL & $0 \%$ & SOMETH. & $10.4 \%$ \\
\hline
\end{tabular}

Tromsø dialect speakers, we find tendencies of the same variation: de (THEY) is sporadically used in both subject and oblique positions, and the SEN variant of SOME (noen) is found.

The low rate of SEN variants of I, ME, YOU.SG, and SHE in CTD indicates that this should not be attributed to levelling or other factors not pertaining to role play. Rather, it could be the case that the play situations that prompts code-switching is not completely covered by the researcher's categories of coding. It may also be the case that the children are still in the process of mastering this code-switching, and that variants may sporadically 'bleed' or 'spill over' into the children's out-of-play utterances in situations where they are engaging in role play (see the discussion of linguistic contamination in Eide \& Åfarli (this issue)).

Returning to RPR and looking at the rate of SEN in pronouns and possessive determiners, we find considerable variation (Table 6). The pronouns can be categorised into four groups. In the first group, we find the pronouns that have separate oblique forms in SEN but are syncretic in TTD, i.e. HER and THEM, just discussed above. In the second group, we find pronouns that have the same variability as CTD or have been completely levelled in the CTD (cf. Table 4 above). This group consists of THEY (82.3\% SEN variants), SOME (92.5\%) and has a high percentage of SEN variants. In the third and fourth categories, we find the remaining pronouns, that neither have subject-marking differences nor are levelled in the children's dialect. These either have a quite low rate of SEN variants in the corpus - the third group, consisting of SHE (32.8\% SEN variants), YOU.PL (14.3\%), and SOMETHING $(14 \%)$ - or a quite high rate of SEN variants in the corpus - the fourth group, consisting of I (74.5\% SEN variants), ME (69.5\%), YOU.SG (65.7\%), and REFL (69.2\%).

Moving on to the variation between recordings, and limiting the discussion to the variables with more than 126 observations, we can start with the most frequent variable, I: Figure 2 shows that some children have a high rate already from the earliest recordings (Celice and Morten), whereas others display a clear change toward a higher rate of SEN variants. Except for a strange dip in the end we see the same general tendency for ME in Figure 3, with an increase in rate of SEN variants from around $50 \%$ to around 70\% averaged. For YOU.SG, in Figure 4, the pattern is less clear than for I and ME, perhaps due to a lower N. As with ME, it starts out around $50 \%$, and ends up at around $70 \%$ averaged. There is also a larger variability in the recordings, and those with the largest excursions in the rate of SEN variants, are also the with the least number of observations (Klara and Kimbo, see Table A4 in Appendix B). The variation in YOU.PL, however, (presented in Figure 5), does not show the same variation as the previous three, but displays a completely different pattern. This is the least frequent of the variables for which the variation in rates 
Table 6. Number and rate of variants of pronouns in the children's RPR

\begin{tabular}{|c|c|c|c|c|c|c|}
\hline Variable & $\mathrm{n}$ & SEN & TTD & other & SEN(\%) & Gloss \\
\hline 1 & 2,805 & 2,092 & 707 & $6(æ i)$ & $74.5 \%$ & ‘’ \\
\hline ME & 354 & 246 & 106 & $2(1)$ & $69.5 \%$ & 'me/myself' \\
\hline YOU.SG & 239 & 157 & 82 & & $65.7 \%$ & 'you/yourself' \\
\hline REFL & 13 & 9 & 4 & & $69.2 \%$ & '-self' (3rd person) \\
\hline SHE & 58 & 19 & 37 & 2 (henne) & $32.8 \%$ & 'she' \\
\hline HER & 18 & 0 & 15 & 3 & $0 \%$ & 'her' \\
\hline YOU.PL & 181 & 26 & 155 & & $14.3 \%$ & 'you $(p l) /$ yourselves \\
\hline THEY & 34 & 6 & 28 & & $82.3 \%$ & 'they' \\
\hline THEM & 13 & (4) & (4) & $9(d e)$ & - & 'them' \\
\hline HIS & 1 & 0 & 1 & & $0 \%$ & 'his' \\
\hline OUR.F/M & 34 & 7 & 27 & & $20.6 \%$ & 'our' (m./f.) \\
\hline OUR.N & 27 & 5 & 22 & & $18.5 \%$ & 'our' (n.) \\
\hline OUR.PL & & 0 & 2 & & $0 \%$ & 'our' (pl.) \\
\hline YOUR & 19 & 2 & 17 & & $10.5 \%$ & 'your' (pl.) \\
\hline THEIR & 3 & 0 & 3 & & $0 \%$ & 'their' \\
\hline SOME & 40 & 37 & 3 & & $92.5 \%$ & 'some(one)' \\
\hline SOMETH. & 50 & 7 & 43 & & $14 \%$ & 'some(thing)' \\
\hline
\end{tabular}

are presented $(\mathrm{N}=181)$. This limits how much we can say about potential development.

(Numbers and rates for I, ME, YOU.SG, and YOU.PL broken down for subjects and groups of recordings are found in Tables A2, A3, A4, A5 respectively, in Appendix B.)

\subsection{BE}

$\mathrm{BE}$ is attested in both its SEN and TTD variant in RPR. Examples are given in (11).
It is.SEN fire 'there's a fire!'
a. Det er brann
b. her er jeg bestemor ((3)Morten, 3;4) here is.SEN I grandma 'here I am, grandma' ((27)Hedda, 4;1)

The rate of SEN variants in CTD of BE is $2.2 \%$. It is reasonable to assume that the explanation of the $2.2 \%$ lies along the same lines as I, ME, YOU.SG, and SHE above: 
Table 7. Number and rate of BE variants in RPR

\begin{tabular}{lccccc}
\hline lemma/variable & $n$ & SEN & TTD & SEN(\%) & gloss \\
\hline (BE:) være & 1,343 & 436 & 907 & $32.4 \%$ & 'be' \\
\hline
\end{tabular}

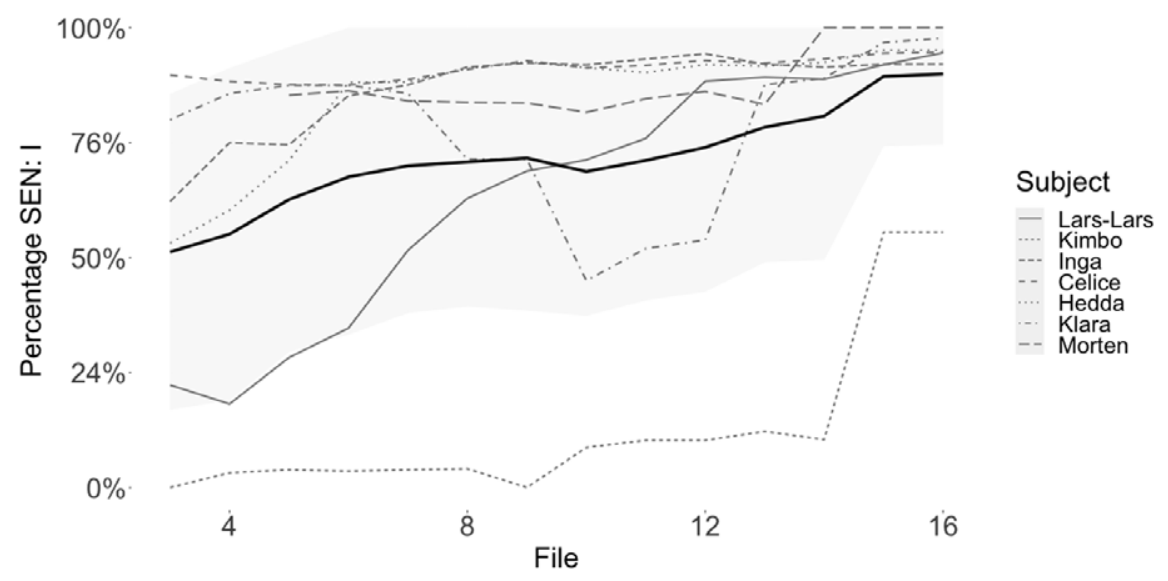

Figure 2. Rolling sums of five recordings (grey lines), mean and standard deviation of rolling sums of five recordings (black line and shaded area) of I.

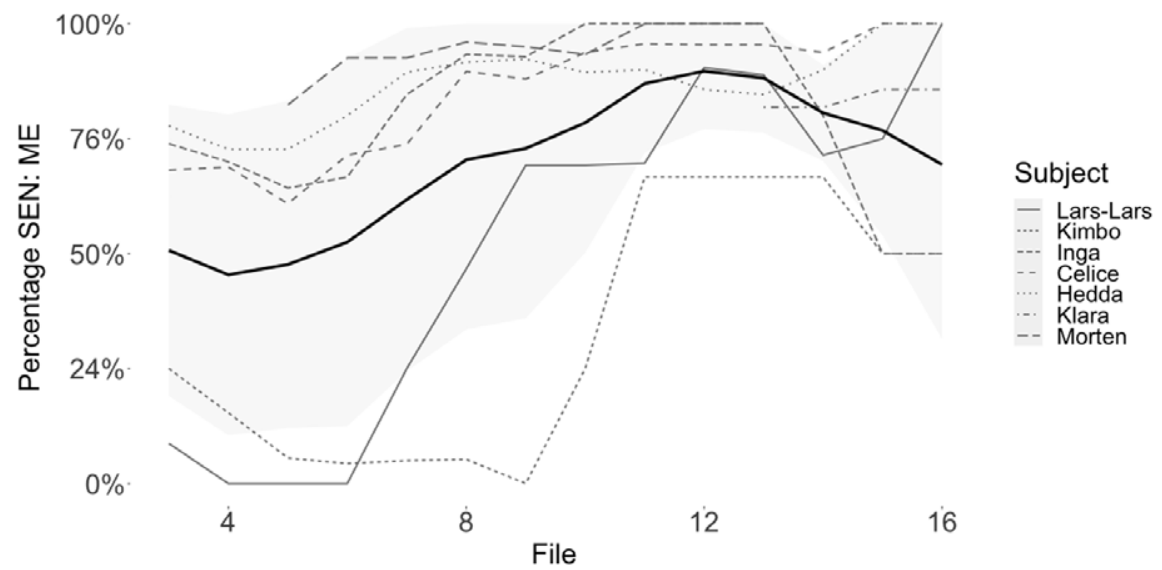

Figure 3. Rolling sums of five recordings (grey lines), mean and standard deviation of rolling sums of five recordings (black line and shaded area) of ME.

Coding mismatches and/or 'bleed'. Returning to RPR, the SEN variant of BE is used is used in overall a third of the time. If we look at the development across recordings and subject (Figure 6), it tells a somewhat different story from the one observed with the three most frequent pronouns, I, ME, and YOU.SG. In the figure, we see a clear development in the mean value, but also on an individual level (e.g. Lars-Lars). 


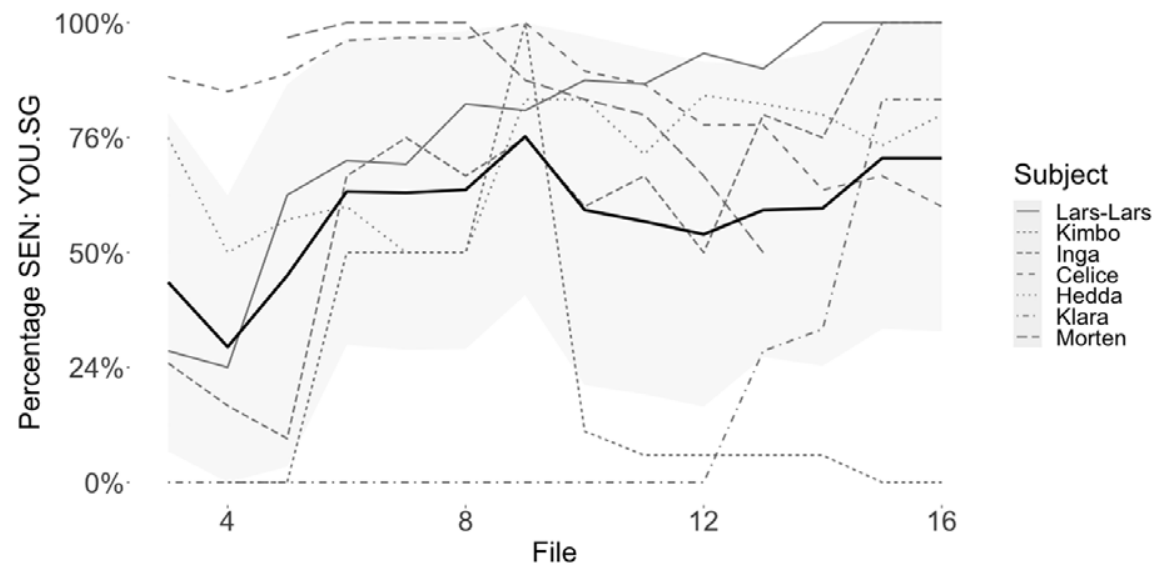

Figure 4. Rolling sums of five recordings (grey lines), mean and standard deviation of rolling sums of five recordings (black line and shaded area) of YOU.SG.

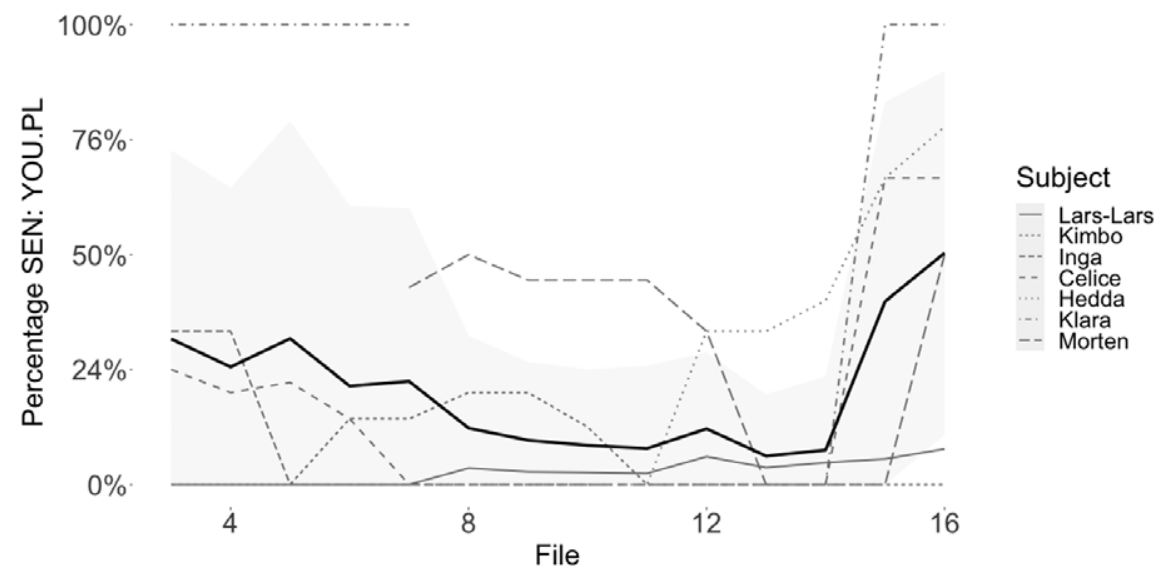

Figure 5. Rolling sums of five recordings (grey lines), mean and standard deviation of rolling sums of five recordings (black line and shaded area) of YOU.PL.

\subsection{Mixed effect analysis}

The seeming development (or lack thereof) in the figures above may be an effect of skewed-ness in that the instances are not distributed evenly across subjects and recordings. In addition, recording number is only an indirect measure of age. To ascertain whether there is a real effect of development, a binomial regression analysis was run on the data to test whether rate of SEN variants in the data increases as an effect of age in the two most frequent variables, I and BE. To do this, age was converted to a decimal (number of months).

Using the programme R (R Core Team 2019) and the package lme4 (Bates et al. 2015), a binomial generalised mixed effect analysis was fitted on all data points (i.e. 
$100 \%$

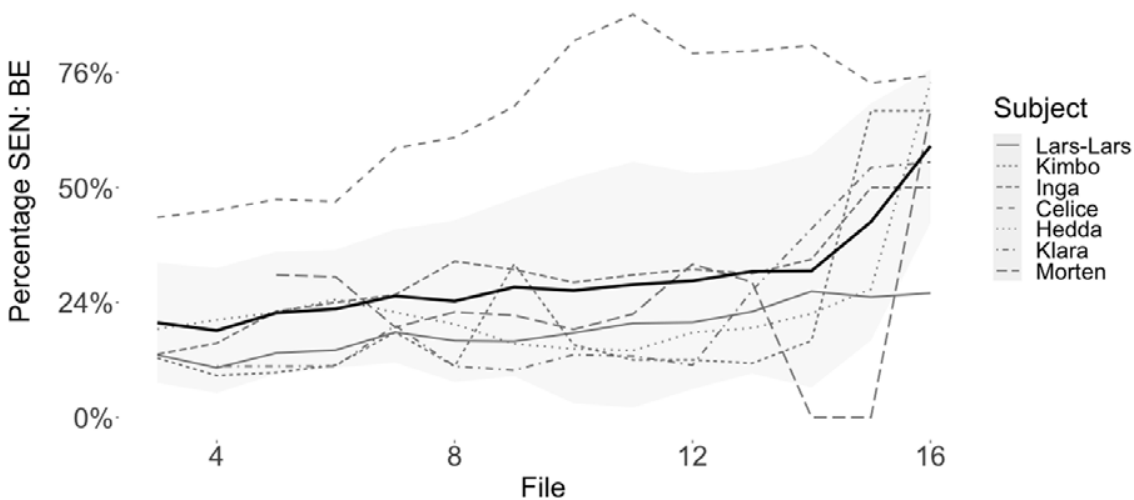

Figure 6. Rolling sums of five recordings (grey lines), mean and standard deviation of rolling sums of five recordings (black line and shaded area) of $\mathrm{BE}$.

all instances as a binary measure as either SEN (1) or not SEN (0), with instances of 'other' left out), with age as a fixed effect and by-subject random slopes for the effect of age to control for different developmental trajectories. In both variables, the effect of age turned out to be significant: I $(\beta=0.26702, S E=0.06224, p<.001)$ and $\mathrm{BE}$ $(\beta=0.22505, S E=0.04785, p<.001)$. In other words, it is unlikely that the changes in the rate of SEN in these two variables are due to random variation. This should however not be a surprise, when we look at the development in Figures 2 and 6.

\section{Discussion}

Having seen the result, we can revisit the three research questions:

1. To what extent do the children use SEN variants or other variants alien to the local dialect in their RPR?

The children in this study use the SEN variant of all the variables of which we had sufficient instances to conclude in this regard, with a few exceptions. This includes most of the pronominal system (Table 1), nominal inflection (Table 2), and present tense of copular be (Table 7). The few exceptions were the forms in which SEN has differential argument marking and TTD has syncretism (SHE/HER and THEY/THEM). The children never used the non-subject SEN-variant of HER (i.e. henne) in a non-subject position, but they did use it in subject position (see Kleemann 2015). Regarding THEY/THEM, the children used the forms seemingly in free variation with no regard to subject-hood. In many ways, this study goes a long way in confirming the findings in Eliassen (1998), and bolsters the numerous reports that children use SEN variants in their RPR with empirical data. 
Furthermore, the results could shed light on the debate about the existence of a standard variety in Norway.

2. What is the rate at which the SEN (or other) variants are used in RPR?

The consistency with which the children used the SEN variants varied greatly between the variables and between children and recordings, even within the pronominal system. Above we divided the pronouns into four groups, where the first two are the ones where argument marking pattern differently between SEN and TTD, and the ones where we see indications of levelling in CTD.

The third and fourth groups are the groups where there is no or little levelling in the children's dialect, and the rate of SEN is relatively low - the third group - or high - the fourth group. The third group consists of SHE (32.8\% SEN), HER (0\%), YOU.PL (14.3\%), and, possibly, SOMETHING (14\%, but see Section 4.2). The fourth group consists of I (74.5\% SEN), ME (69.5\%), YOU.SG (65.7\%) and REFL (69.2\%). Compared to the first two groups, it is not as obvious why these groups have a high or low rate of SEN variants in the data. Three possible explanations are suggested.

The first possible explanation is rooted in the pragmatics of 1 st and 2 nd person pronouns. As proposed by Errington (1985), morphemes have a relative pragmatic salience: The more pragmatically salient a morpheme is, the more likely it is to be used to index social relations in the discourse (Woolard 2008). Personal pronouns are among the most pragmatically salient groups of morphemes, as they index $s u b$ jective interactional stances (Woolard 2008: 443). Keep in mind that the role of RPR can be regarded as staging the child's role persona as different from her every-day persona (cf. auto-divergence, endnote 5). Both first and second person pronouns are ideal nuclei for such stance-taking. The first person singular pronouns (I/ME) refer to the speaker herself, and should be obvious in this regard.

The second person singular pronoun indexes the relation between the speaker and the addressee (as evident in honorifics, Silverstein 2003), and the use of the SEN variant of this can be interpreted as including the addressee in the pretence of the role play and/or indexing the speaker's role persona in relation to the addressee. A problem with this explanation is the fact that the REFL variable also has a high rate of SEN, and that the second person plural pronoun YOU.PL has a low rate of SEN as opposed to its singular counterpart. The former can be explained by the fact that it may be a random effect of the low numbers of instances of the variable in total, and the latter with the fact that second person plural pronouns (often) include someone who is not directly part of the speaker/addressee dyad. The need for these additional assumptions speak against this explanation.

The second possible explanation may be the most obvious one: It depends on frequency alone. The most frequent ones are the ones that they pick up on quickest. In turn, there may be a number of explanations for this, the most promising being the fact that the output represented in the material reflects the children's input (cf. the discussion in Section 1.1). The variables most frequently produced in role play are necessarily the same variables most frequently heard in role play. This gives a reinforcing effect, speeding up the consolidation towards agreed-upon role play variants. This does however not explain why there is such a steep decline in the rate of 
SEN from the third most frequent pronoun, YOU.SG with 240 instances and $70 \%$ SEN, to the fourth most frequent, YOU.PL with 181 instances and 16\% SEN. In addition, as with the previous explanation, in order for the frequency explanation to work we would have to assume that the high rate of SEN variant in REFL is a fluke due to its low frequency in the material, and that the rate would decrease drastically, should there be more instances of it.

This is a segue into the third possible explanation. All the pronouns in the fourth group end in [-æ:] in the Tromsø dialect, and in [-æi] in SEN (see Section 1.3). These parallel patterns are easily generalised upon, which makes them conceptually grouped together. Indeed, to 'transform' from [æ:] to [jæi], [mæ:] to [mæi], etc. requires relatively few permutations, at least compared to the other pronouns (e.g. dokker to dere, ho to hun, etc.). The attested hybrid form [æi] may also be indicative of this. The conceptual grouping may give a feedback effect which the other variables in the group feed upon.

Disentangling which of these explanations plays the most important role, either alone or in synergy with one another, would need a triangulation of ethnomethodological and quantitative approaches which would be beyond the scope of this paper. Indeed, there may be a combination of all explanations at play: It is not improbable that the pragmatic qualities of I and ME have an impact on their frequency in role play, which start the feedback effect mentioned above, increasing the rate of SEN in I and ME. Subsequently, YOU.SG and REFL piggyback on the development of I and ME due to their phonological similarity, resulting in the high rate of SEN variants in the third group. The members of the second group (SHE, HER, YOU.PL, SOMETHING) either do not have the same pragmatic qualities, (n)or the phonological resemblance to pronouns that do, and lag behind in relation to the rate of SEN variants.

Regarding BE, the other variable analysed quantitatively, the rate of SEN variants averaged on $32.4 \%$, and can thus be regarded as quite emblematic (salient), although not in the same league as the group of highly salient pronouns discussed above (I, ME, YOU.SG, REFL).

To sum up this discussion, all the three possible explanations feature some sort of salience - pragmatic, phonological and/or in the input (i.e. frequency) - as an explanatory concept. Without taking the space to elaborate on the definition of salience, we can note that the use of this notion is a tip of the hat to the variationist-inspired definition of RPR as auto-divergence, i.e. dialect divergence from oneself (see endnote 5), as it is an often used explanatory concept in studies of convergence and divergence.

3. Is there a change or development over time in the extent or consistency that children use these variants in their RPR?

Lastly, we saw that across multiple variables, there was a development in the rate of SEN variants used in RPR (tested statistically for I and BE). This clearly indicates a development over time. Although any type of language acquisition necessarily will develop incrementally, as discussed in Section 1.2, there is an important difference between this case and second language acquisition. Whereas both cases are instances of language acquisition which happens on top of and beyond the first language, the 
case of the Northern Norwegian RPR, as attested in the present subjects, seem to bifurcate with the first language (the local dialect), i.e. very incrementally diverge, in ways and to degrees second language acquisition does not (but see the discussion in Section 1.2).

The difference in development is one manner in which the RPR differs from other situations of bilingualism and bidialectalism, and it may have ramification for its cognitive status vis a vis the local dialects it builds on. This study has only looked at the difference in surface forms, and an obvious way ahead would be to investigate whether there are also syntactical differences or differences in the phonological systems between an RPR and its local dialect. It may be the case that the RPR only entails a shift in the surface (phonetic) form of lexical and morphological material, in which case it would be substantially different from other forms of bidialectalism.

A second way RPR may differ from other situations of bidialectalism as portrayed in this issue is in the priming of the cognitive index of the register (see Section 1.2): It is exclusively pragmatic, relating to real world events only. This is opposed to the system of universal multilingualism as proposed by Roeper (1999), which is conditioned upon lexical material (see also the discussion in Eide \& Åfarli (this issue) on how word order in interrogatives is primed by the choice of $w h$-word). However, the choice of lexical material can similarly be primed by pragmatic factors (such as the choice of a 'standard' or 'dialect' wh-word). The snake bites its tail: Roeperian bidialectalism may also be cases of pragmatically conditioned register variation, indirectly. A relevant question pertaining to RPR would then be whether the use of a lexeme, for example a wh-word, would trigger SEN syntax, for example in interrogative clauses (see Lundquist et al. (this issue) on syntactic variation in the Tromsø dialect compared to SEN), or whether the child would produce TTD syntax with the SEN variant. (Or rather whether the child would eventually pick up on the SEN syntax.) This is connected to the question of the status of the RPR vis a vis SEN, which again is connected to the discussion of a standard spoken variety of Norwegian and whether there is one (see Section 1.3): It depends on whether the RPR is only stored as a collection of emblematic features used to signal role play, or whether it is represented as a coherent variety corresponding to SEN (to some degree) in the child's linguistic competence. It may not be the one or the other for all children, and it may develop from the former to the latter. In any event, if the latter is the case, for all or some children, then it would represent a very strong argument in favour of SEN as a de facto standard variety. If the former is the only case, the argument holds, although weaker: The choice of specifically SEN as the source of these emblematic forms indicates that it holds some special status above other Norwegian varieties. The apparent directionality and development toward more SEN variants may indicate that SEN, or some version of it, is a target variety of sorts, possibly transferred across age groups from older to younger children as a part of child folklore, as discussed in the background section. If this is the case, it could be argued, speculatively, that the situation is closer to a 'coherent variety' (the latter case above) than sporadic emblematic features. 


\section{Conclusion}

This paper reports a multiple case study of seven Northern Norwegian children's use of Standard East Norwegian (SEN) variants of morphological variables in their role play register (RPR). The paper set out to answer the extent to which i) SEN variants were used in the RPR, ii) they were used consistently, and iii) whether there was a development in the rate of SEN variants.

In accordance with previous research, children were found to use the SEN variant of most of the variables alongside the local dialect variants. The rate at which they do so varies across variable, subject and time. Within the pronominal system, a number of pronouns seem to be adjunctly highly emblematic in RPR, and therefore more frequent than others in their SEN variant. These were the equivalents of $I, m e, y o u$ and him-/herself. I discussed whether this may be due to the pragmatic salience of the singular first person pronouns in being the locus for subjective interactional stances, especially in role play where the child signals the taking-on of another persona, frequency, or the phonological similarity between the four forms. I concluded that the latter was intuitively the most promising explanation, as it explains the data without relying on any auxiliary hypotheses, although possibly at work in combination with the other two.

By fitting a binomial mixed effect analysis on the two most frequent variables (present tense of the copular and the pronoun I), a significant effect of age on the rate of SEN variants was found. The interpretation of this was that SEN features in RPR develops over time and that the children's native dialect and the RPR overlap, at least initially, but diverge over time, and furthermore that there is a directionality in the form of the RPR which may indicate that (at least some variables of) SEN functions as a target variety of sorts.

\section{Notes}

1 List of abbreviations and variable names: BE: Present tense of copular 'be' variable (e/er); CTD: (The) Children (of this study)'s Tromsø Dialect; DEF/def.: Definite; F/f.: Feminine; HER: Third person singular feminine non-subject pronoun variable (ho/henne); HIS: Third person masculine possessive variable (hannes/hans); I: First person singular subject pronoun variable (o/jeg); indef.: Indefinite; M/m.: Masculine; ME: First person singular non-subject pronoun variable ( $m \propto / m e g)$; N/n.: Neuter; obl.: Oblique/non-subject; OUR: First person plural possessive variable (vårres, vårs/vår(-t, -e)); p.-ee: Possessee; PL/pl.: Plural; p.-or: Possessor; PRES.: Present tense; REFL: Third person reflexive pronoun variable (s e/seg); RPR: Role play register; SEN: Standard East Norwegian; SG/sg.: Singular; SHE: Third person singular feminine subject pronoun variable (ho/hun); SOME: Indefinite pronoun/determiner variable (nokken, nån/noen); SOMETHING: Indefinite pronoun/determiner variable (nokka/noe); THEIR: Third person plural possessive variable (demmes/deres); THEM: Third person plural non-subject pronoun variable (dem/dem); THEY: Third person plural subject pronoun variable (dem/de); TTD: Traditional Tromsø Dialect; YOU.PL: Second person plural pronoun variable (dokker/dere); YOUR: Second person plural possessive variable (dokkers/deres); YOU.SG: Second person singular non-subject pronoun variable ( $\mathrm{d} e / \mathrm{deg})$.

2 There is a discussion to be had about the proper definition of 'role play register', and how it relates to notions such as 'development' and 'competence'. Since this terminological specification is not vital for the interpretation of the result, it will be cleared up in this endnote so as not to inflate the paper. First and foremost, the term 'role play register' is understood to be functional, i.e. 'whatever linguistic and paralinguistic features any child uses at any time to signal role utterances', and it is per definition individual and variable. Secondly, one can look at the socially agreed upon norms for characteristics of role play registers within a population (play group, kindergarten, region, country, etc.), itself also containing variation. This 
could have been termed the 'role play variety'. To the extent the notions 'development' and 'competence' are used in this paper, they are not to be understood as more or less complete acquisition of SEN or the role play register per se. (The latter would be self-contradictory given the definition above.) Rather, for the sake of argument, we can view the role play register (i.e. 'variety'), as a cline with the features of the child's every day speech in the one end, and 'alien features' in the other, where 'development' - to the extent it is encountered - is to be construed as the movement of the recorded role play register (i.e. 'variety') from one end to the other of this cline, i.e. from less to more 'alien features'.

3 The first written source I have been able to find of the phenomenon is in an autobiographical novel by Sigrid Undset (referred to in Høigard 1999), set in the 1880's, where children engaging in role play are described as 'speaking [ ... ] in a sort of book language' in their role utterances (Undset 1994 [1934]: 84, my translation) (the term 'book language' (bogsprog) here is not a reference to the written standard bokmål).

4 Folk-linguistically, the source of SEN as a RPR has been attributed to television (discussed in Høigård 1999), and in particular children's television. Although many sources predate the introduction of television to Norway, we cannot exclude that it has some influence on the form of the RPR of children of today. However, the time children use playing and interacting with each other by far eclipses the time children spend watching television (Medietilsynet 2018). In addition, the extent to which children can acquire language through television is highly disputed (Gola et al. 2012), although a recent case study of a Norwegian four year old acquiring English allegedly solely through YouTube (Kalstad 2019) brings this into perspective, possibly indicating a division between first and second language acquisition.

5 In dialect-sociological accounts, this process must be regarded as a kind of dialect divergence, where the child's RPR represents a divergence from her own native dialect; we can call this auto-divergence.

6 Thanks to an anonymous reviewer for pointing this out.

7 Vanvik (1985: 13) uses the term 'Standard East Norwegian' for the variety prescribed in his pronouncing dictionary.

8 All forms will be given in orthographic (for SEN) and semi-orthographic (for TTD) transcript. The semiorthographic transcript uses the Norwegian alphabet and orthography to approximate the pronunciation of TTD. Phonetic transcriptions will be given in the main text where it is relevant. The variables will be referred to by all capital letter terms of English equivalents (e.g. ME for first person singular non-subject pronoun $m e g$ or $m e$ and YOU.SG for second person singular non-subject pronoun $\mathrm{deg}$ or $d \propto e$ ). These are added in the tables, see the list of abbreviations in endnote 1.

9 Of the pronouns in Table 1, SHE and THEY can be used as demonstratives as well (see Vindenes 2018: 18). In demonstrative uses, they are always stressed and have the same form even in oblique positions, and these have been counted with the subject variants, even in oblique positions (i.e. SHE and THEY, not HER and THEM).

(i) jeg har glømt de her (Lars-Lars, 3;2)

I have forgotten they here

'I have forgotten these'

In addition, some Norwegian dialects, and Northern Norwegian in particular, have a proprial article (see Johannessen \& Garbacz 2014), which is isomorphic with the personal pronouns he and she, and which SEN does not have.

$\begin{array}{llllll}\text { (ii) jeg kan leke meg med ho Celice } & \text { (Celice, 2;11) } \\ \text { I.SEN can play } & \text { me.SEN } & \text { with } & \text { she.TTD } & & \\ \text { 'I can play with C.' } & & & & \end{array}$

This morpheme is left out of the analysis here.

10 YOU.SG is the non-subject equivalent of $y o u$. REFL is the 3rd person reflexive pronoun, both singular (him-/herself) and plural (themselves).

11 Children and adolescents growing up speaking the Oslo dialect, which is close to or identical to SEN, tend to not mark subjects and oblique arguments differently for 3rd person pronouns. This includes feminine, (hun and henne), masculine (han and ham, but see endnote 3), and plural (de and dem). A quick corpus search in a speech corpus from Oslo (NoTa Corpus) confirms this. 
12 There is a subtle phonological difference between SEN and TTD variant of the THEM whereby the vowel is more open in the latter ([dem] vs. [dæm], respectively). This is connected to a general vowel shift in northern dialects whereby all originally short front vowels in certain contexts have become more open (lågning, lit. 'lowering', Iversen 1913; Skånlund 1933). This means that if children use a closed vowel in this variable, we cannot ascertain whether she is adopting SEN morphology or SEN phonology. I.e. it is impossible to decipher whether she uses the SEN morpheme [dem] or whether she uses the TTD morpheme [dæm] but adopts SEN phonology, reverses 'lowering' and raises the vowel to [e]. Crucially, the other differences between SEN and TTD mentioned here cannot be explained by such general phonological differences between Norwegian dialects alone.

13 Traditionally, SEN has marked the masculine singular third person pronoun differently in subject and oblique position, as in English 'he' and 'him' (han and ham respectively), but a syncretic paradigm (han, han) has been codified in the written standard since 1917 (Språkrådet 2008). Since this gives an overlap between SEN and TTD in this variable, it is not investigated further in this study.

14 According to Bull (1990: 220), the Tromsø dialect has the forms nåkka and nåkken, but in the speech corpus (LIA Corpus), we find the form nån as well.

15 The addition of five children after recording 16 was due to an expansion of one of the kindergarten's groups.

16 The change in recording equipment was due to a change of rooms and thereby the loss of possibility to hang the microphones from the ceiling.

17 For two recordings the audio recording from the recording device was lost due to human error. Audio from the session was still recorded through the visual recording device, although in a much inferior quality. The two files in question have not been included in this study.

18 The transcriptions were made over an extensive period of time, and a series of versions of ELAN were used, spanning from 4.9.4 to 5.7-AVFX.

19 Digital Object ID for replication data: https://doi.org/10.18710/TU1GSY

20 The rationale behind this number is the number of subject times the number of recordings $(7 \mathrm{x}$ $18=126)$, i.e. the variables are observed on average at least once for every child for every recording.

21 The asterisk in examples (7) and (9) indicates that the verb form is unconventional, both in relation to SEN and TTD. In these cases it is an example of regularisation of the past tense form of an originally strong paradigm (semi-orthographic: hjalp - ${ }^{*}$ hjelp-a, skøyt/skaut (TTD) or skjøt (SEN) - ${ }^{*}$ skyt-a).

\section{References}

Allern, Tor-Helge. 1995. Drama og kommunikasjonsteori. Nesna: Høgskolen i Nesna.

Åm, Eli. 1989. På jakt etter barneperspektivet [Chasing the children's perspective]. Oslo: Universitetsforlaget. Andersen, Elaine. 2014 [1990]. Speaking with Style: The Sociolinguistic Skills of Children. Hoboken: Taylor and Francis.

Aronsson, Karin. 2011. Language socialization and verbal play. In Duranti et al. (eds.), 464-483.

Auwärter, Manfred. 1986. Development of communicative skills: The construction of fictional reality in children's play. In Jenny Cook-Gumperz, William A. Corsaro \& Jürgen Streeck (eds.), Children's Worlds and Children's Language, 205-230. The Hague: Mouton de Gruyter.

Bailey, Charles-James N. 1973. Variation and Linguistic Theory. Arlington, VA: Center for Applied Linguistics.

Bates, Douglas, Martin Mächler, Ben Bolker \& Steve Walker. 2015. Fitting linear mixed-effects models using lme4. Journal of Statistical Software 67(1), 1-48. doi: 10.18637/jss.v067.i01.

Bjørlykke, Bjørn. 1996. Barnespråk og barnekultur opp til sju år [Children's language and children's culture up to seven years]. Oslo: Cappelen akademisk forlag.

Brugman, Hennie \& Albert Russel. 2004. Annotating multi-media/multi-modal resources with ELAN. In Proceedings of LREC 2004, Fourth International Conference on Language Resources and Evaluation.

Bugge, Edit, Magnhild Selås \& Ann-Kristin Helland Gujord. 2017. Språket i bruk [Language in use]. In Magnhild Selås \& Ann-Kristin Helland Gujord (eds.), Språkmøte i barnehagen, 63-97. Bergen: Fagbokforlaget.

Bull, Tove. 1990. Tromsø bymål [Urban Tromsø dialect]. In Ernst Håkon Jahr (ed.), Den store dialektboka. 217-221. Oslo: Novus forlag. 
Bull, Tove. 2009. Standardtalemål i Norge?: Eit spørsmål om pavens skjegg? [Standard spoken language in Norway?: A question of the pope's beard?] Norsk Lingvistisk Tidsskrift 27(2). 221-238.

Chomsky, Noam. 1965. Aspects of the Theory of Syntax. Cambridge, MA: MIT Press.

Cromdal, Jakob \& Karin Aronsson. 2000. Footing in bilingual play. Journal of Sociolinguistics 4(3), 435-457.

Duranti, Alessandro, Elinor Ochs \& Bambi B. Schieffelin (eds.). 2011. The Handbook of Language Socialization. Oxford: Wiley Blackwell.

Eide, Kristin Melum \& Tor A. Åfarli. this issue. Dialects, registers and intraindividual variation: Outside the scope of generative frameworks? Nordic Journal of Linguistics.

ELAN, (Version 5.7-AVFX) [computer program]. (03.06.2019). https://tla.mpi.nl/tools/tla-tools/elan/.

Eliassen, Camilla. 1998. Rollelekspråk [Role play language]. Master thesis, Norwegian University of Science and Technology.

Errington, Joseph J. 1985. On the nature of the sociolinguistic sign: Describing the Javanese speech levels. In Elizabeth Merz \& Richard J. Parmentier (eds.), Semiotic Mediation, 287-310. Orlando, FL: Academic Press.

Ervin-Tripp, Susan. 1973. Language Acquisition and Communicative Choice. Stanford, CA: Stanford University Press.

Ervin-Tripp, Susan. 1991. Play in language development. In Barbara Scales (ed.), Play and the Social Context of Development in Early Care and Education, 84-97. New York, NY: Teachers College, Columbia University.

Fein, Greta G. 1981. Pretend play in childhood: An integrative review. Child Development 52(4), 10951118. doi: $10.2307 / 1129497$.

Garca-Sánchez, Inmaculada M. 2010. Serious games: Code-switching and gendered identities in Moroccan immigrant girls' pretend play. Pragmatics 20(4), 523-555.

Gleason, Jean Berko. 1973. Code switching in children's language. In Timothy E. Moore (ed.), Cognitive Development and the Acquisition of Language, 159-168. New York, NY: Academic Press.

Gola, Alica Ann Howard, Lara Mayeux \& Letitia R. Naigles. 2012. Electronic media as incidental language teachers. In D. Singer \& J. Singer (eds.), Handbook of Children and Media, 139-156. London: Sage Publications.

Goodwin, Marjorie H. \& Amy Kyratzis. 2011. Peer language socialization. In Duranti et al. (eds.), 365-390.

Gravir, Magnhild. 1983. Barnet og talemålet [The child and spoken language]. Oslo: Universitetsforlag.

Green-Väntinen, Maria. 1996. Hej vi har int merirosvo på vårt lag: Kodväxling och lån i tvåspråkiga barns samtal [Code switching and borrowing in bilingual children's conversation]. Svenskans beskrivning 21, $112-121$.

Guldal, Tale Margrethe. 1997. Three Children, Two Languages: The Role of Code Selection in Organizing Conversation. Doctoral thesis, Norwegian University of Science and Technology.

Hagen, Kristin, Live Håberg, Eirik Olsen \& Åshild Søfteland. 2018. Transkripsjonsrettleiing for LIA [Transcription guide for LIA]. Electronic. http://www.tekstlab.uio.no/LIA/pdf/ transkripsjonsrettleiing_lia.pdf.

Halmari, Helena \& Wendy Smith. 1994. Code-switching and register shift: Evidence from Finnish-English child bilingual conversation. Journal of Pragmatics 21(4), 427-445. doi: 10.1016/0378-2166(94)90013-2.

Harris, Judith Rich. 1995. Where is the child's environment? A group socialization theory of development. Psychological Review 102(3), 458-489.

Hickman, Maya, Edy Veneziano \& Harriet Jisa. 2018. Introduction. What can variation tell us about first language acquisition? In Maya Hickman, Edy Veneziano \& Harriet Jisa (eds.), Sources of Variation in First Language Acquisition, 1-24. Amsterdam/Philadelphia: John Benjamins Publishing Company. doi:https://doi.org/10.1075/tilar.22.

Høigård, Anne. 1999. Barns språkutvikling: muntlig og skriftlig [Children's linguistic development: oral and written]. Oslo: Tano Aschehoug.

Iversen, Ragnvald. 1913. Senjen-maalet: lydverket $i$ hoveddrag [The Senja dialect: the sound system in outline]. Kristiania: Jacob Dybwad.

Iversen, Ragnvald. 1918. Syntaksen $i$ Tromsø bymaal: en kort oversigt [The syntax of urban Tromsø dialect: a brief overview]. Kristiania: Bymaals-laget. 
Jahr, Ernst Håkon \& Britt Mæhlum. 2009. Har vi et "standardtalemål" i Norge? [Do we have a "standard spoken variety" in Norway?] (Special issue). Norsk Lingvistisk Tidsskrift 27(1).

Johannessen, Janne Bondi \& Piotr Garbacz. 2014. Proprial article. Nordic Atlas of Language Structures (NALS) Journal 1, 10-17.

Johannessen, Janne Bondi, Joel Priestley, Kristin Hagen, Tor Anders Åfarli \& Øystein A. Vangsnes. 2009. The Nordic Dialect Corpus - an advanced research tool. In Kristiina Jokinen \& Eckhard Bick (eds.), Proceedings of the 17th Nordic Conference of Computational Linguistics NODALIDA, vol. 4 NEALT Proceedings Series.

Kalstad, Pål Hunstad. 2019. Child Second Language Acquisition Without Communication. UiT - The Arctic University of Norway MA thesis.

Kerswill, Paul. 1994. Dialects Converging. Oxford, UK: Clarendon Press.

Kleemann, Carola. 2013. Play in two languages. Language alternation and code-switching in role-play in North Sámi and Norwegian. Nordlyd: Tromsø University Working Papers on Language \& Linguistics/ Institutt for Språk og Litteratur, Universitetet $i$ Tromsø 39(2), 47-69.

Kleemann, Carola. 2015. Lek på to språk: en studie av språkalternering og kodeveksling $i$ tospråklig rollelek på nordsamisk og norsk $i$ en samisk barnehage [Play in two languages: a study of language alternation and code switching in bilingual role play in North Sámi and Norwegian]. Doctoral thesis, University of Tromsø.

Larson, Karen Ann. 1985. Learning Without Lessons: Socialization and Language Change in Norway. Lanham, MN: University Press of America.

LIA. Corpus. Language infrastructure made accessible. http://tekstlab.uio.no/LIA/.

Lundquist, Björn, Maud Westendorp \& Bror-Magnus S. Strand. this issue. Code-switching alone cannot explain intraspeaker syntactic variability: Evidence from a spoken elicitation experiment. Nordic Journal of Linguistics.

Mæhlum, Brit. 1992. Dialektal sosialisering: en studie av barn og ungdoms språklige strategier $i$ Longyearbyen på Svalbard [Dialectal socialization: a study of children's and adolescent's linguistic strategies in Longyearbyen, Svalbard]. Oslo: Novus forlag.

Mæhlum, Brit. 2009. Standardtalemål? Naturligvis! En argumentasjon for eksistensen av et norsk standardtalemål [Standard spoken language? Of course! An argument for the existence of a Norwegian standard spoken variety]. Norsk Lingvistisk Tidsskrift 27(1), 7-25.

Medietilsynet. 2018. Foreldre og medier-undersøkelsen 2018 [Parents and media survey 2018]. Digital.

Nesse, Agnete \& Hilde Sollid. 2010. Nordnorske bymål i et komparativt perspektiv [Northern Norwegian urban dialects in a comparative perspective]. Maal og Minne 102(1), 137-158.

Nicolopoulou, Ageliki. 2018. Pretend and social pretend play. In Peter K. Smith \& Jaipaul L. Roopnarine (eds.), The Cambridge Handbook of Play, 183-199. Cambridge, UK: Cambridge University Press.

Nordic Dialect Corpus. (Corpus). Nordic dialect corpus. http://tekstlab.uio.no/nota/scandiasyn/.

NoTa. Corpus. Norsk talespråkskorpus - Oslodelen, Tekstlaboratoriet, ILN, Universitetet i Oslo. http:// www.tekstlab.uio.no/nota/oslo/index.html.

R Core Team. 2019. R: A language and environment for statistical computing. R Foundation for Statistical Computing Vienna, Austria. https://www.R-project.org/.

Roeper, Thomas. 1999. Universal bilingualism. Bilingualism: Language and Cognition 2(3), 169-186.

Røyneland, Unn. 2009. Dialects in Norway: catching up with the rest of Europe? International Journal of the Sociology of Language 196/197, 7-30.

Sandøy, Helge. 2009. Standartalemål? Ja, men ! Ein definisjon og ei drøfting av begrepet [Standard spoken language? Yes, but ! A definition and a consideration of the term]. Norsk Lingvistisk Tidsskrift 27(1), 27-47.

Silverstein, Michael. 2003. Indexical order and the dialectics of sociolinguistic life. Language and Communication 23, 193-229. doi:https://doi.org/10.1016/S0271-5309(03)00013-2.

Sjekkeland, Martin. 2005. Dialektar i Noreg [Dialects in Norway]. Kristiansand: Høyskoleforlaget.

Skånlund, Einar B. 1933. Saltamålet: kort oversikt over lydverket [The Salta dialect: short overview of the sound system]. Oslo: Aschehoug.

Söderbergh, Ragnhild. 1980. Story-telling, dramatic role play and displaced speech in play with dolls. First Language 1(3), 209-222. doi: https://doi.org/10.1177/014272378000100303.

Språkrådet. 2008. https://www.sprakradet.no/Vi-og-vart/Publikasjoner/Spraaknytt/Arkivet/Spraknytt2008/Spraknytt-22008/Spoersmaal-og-svar/. 
Strömqvist, Sven. 1981. The pragmatics of prosody in children's pretend play. In Thorstein Fretheim (ed.), Nordic Prosody II, 214-227. Trondheim: Tapir.

Strömqvist, Sven. 1984. Make-believe through words: A linguistic study of children's play with a doll's house. Göteborg: Doctoral thesis, Department of Linguistics, University of Göteborg.

Tetzchner, Stephen von, Julie Feilberg, Bente Hagtvet, Harald Martinsen, Per Egil Mjaavatn, Hanne Gram Simonsen \& Lars Smith. 1993. Barns språk [Children's language], 2nd edn. Oslo: Ad Notam Gyldendal.

Undset, Sigrid. 1994 [1934]. Elleve år [Eleven years]. Stabekk: Den norske bokklubben.

Vanvik, Arne. 1985. Norsk uttaleordbok: A Norwegian Pronouncing Dictionary. Fonetisk institutt, Universitetet i Oslo.

Vedeler, Liv. 1987. Barns kommunikasjon i rollelek [Children's comunication in role play]. Oslo: Universitetsforlaget.

Venås, Kjell. 1983. Normalisering [Standardisation]. In Magnhild Gravir (ed.), Barnet og talemålet, 141156. Oslo: Universitetsforlaget.

Vikør, Lars S. 1993. The Nordic Languages: Their Status and Interrelations. Oslo: Novus.

Vindenes, Urd. 2018. Complex Demonstratives and Cyclic Change in Norwegian. Doctoral thesis, University of Oslo.

Woolard, Kathryn A. 2008. Why dat now?: Linguistic-anthropological contributions to the explanation of sociolinguistic icons and change. Journal of Sociolinguistics 12(4), 432-452. 


\section{Appendix A. Age of children at each recording session}

Table A.1. Recordings/Session number and ages (years;months.days). Missing ages indicate absence from the recordings. The reference values indicate the time since the first recording

\begin{tabular}{|c|c|c|c|c|c|c|c|c|}
\hline Ssn. no. & Ref. & Lars-Lars & Celice & Morten & Inga & Hedda & Kimbo & Klara \\
\hline 1 & - & $2 ; 11.16$ & $2 ; 11.27$ & & $2 ; 11.20$ & $3 ; 1.20$ & $2 ; 10.23$ & $2 ; 7.1$ \\
\hline 2 & 0.7 & $2 ; 11.23$ & $3 ; 0.3$ & & $2 ; 11.27$ & $3 ; 1.27$ & $2 ; 10.30$ & $2 ; 7.8$ \\
\hline 3 & 0.14 & $2 ; 11.30$ & $3 ; 0.10$ & $3 ; 4.7$ & $3 ; 0.3$ & $3 ; 2.3$ & & \\
\hline 4 & 0.28 & $3 ; 0.13$ & $3 ; 0.24$ & $3 ; 4.21$ & $3 ; 0.17$ & & $2 ; 11.20$ & $2 ; 7.29$ \\
\hline 5 & 1.10 & $3 ; 0.26$ & $3 ; 1.6$ & $3 ; 5.6$ & $3 ; 1.2$ & $3 ; 3.2$ & $3 ; 0.5$ & $2 ; 8.11$ \\
\hline 6 & 1.20 & & $3 ; 1.16$ & $3 ; 5.16$ & $3 ; 1.12$ & $3 ; 3.12$ & $3 ; 0.15$ & $2 ; 8.21$ \\
\hline 7 & 2.6 & $3 ; 1.22$ & $3 ; 2.2$ & $3 ; 5.30$ & $3 ; 1.26$ & $3 ; 3.26$ & & $2 ; 9.7$ \\
\hline 8 & 2.13 & $3 ; 1.29$ & $3 ; 2.9$ & $3 ; 6.6$ & $3 ; 2.2$ & $3 ; 4.2$ & $3 ; 1.5$ & $2 ; 9.14$ \\
\hline 9 & 2.25 & $3 ; 2.10$ & $3 ; 2.21$ & $3 ; 6.18$ & $3 ; 2.14$ & $3 ; 4.14$ & & $2 ; 9.26$ \\
\hline 11 & 3.17 & $3 ; 3.3$ & $3 ; 3.13$ & $3 ; 7.11$ & $3 ; 3.7$ & $3 ; 5.7$ & & $2 ; 10.18$ \\
\hline 12 & 3.29 & $3 ; 3.15$ & $3 ; 3.25$ & $3 ; 7.23$ & $3 ; 3.19$ & $3 ; 5.19$ & & $2 ; 11.0$ \\
\hline 14 & 4.27 & $3 ; 4.12$ & $3 ; 4.23$ & & $3 ; 4.16$ & $3 ; 6.16$ & $3 ; 3.19$ & $2 ; 11.28$ \\
\hline 15 & 5.3 & $3 ; 4.19$ & & $3 ; 8.27$ & & $3 ; 6.23$ & & $3 ; 0.4$ \\
\hline 16 & 6.22 & $3 ; 6.7$ & $3 ; 6.18$ & $3 ; 10.15$ & & $3 ; 8.11$ & & $3 ; 1.23$ \\
\hline 18 & 7.19 & & $3 ; 7.15$ & & $3 ; 7.8$ & & $3 ; 6.11$ & $3 ; 2.20$ \\
\hline 21 & 9.2 & $3 ; 8.18$ & $3 ; 8.28$ & & $3 ; 8.22$ & $3 ; 10.22$ & $3 ; 7.25$ & $3 ; 4.3$ \\
\hline 25 & 11.9 & $3 ; 10.1$ & $3 ; 11.5$ & & & $4 ; 0.29$ & $3 ; 9.10$ & $3 ; 6.10$ \\
\hline 27 & $1 ; 0.6$ & $3 ; 11.22$ & $4 ; 0.2$ & $4 ; 3.30$ & & $4 ; 1.26$ & & $3 ; 7.7$ \\
\hline
\end{tabular}




\section{Appendix B. Variables across subject and group of recordings}

Table A.2. Rate of SEN in I across subject and group of recordings

\begin{tabular}{|c|c|c|c|c|c|c|c|c|}
\hline \multirow{3}{*}{$\begin{array}{l}\text { name } \\
\text { Lars-Lars }\end{array}$} & \multicolumn{6}{|c|}{ recordings } & \multicolumn{2}{|r|}{ total } \\
\hline & \multicolumn{2}{|r|}{$1-6$} & \multicolumn{2}{|c|}{$7-9,11-12,14$} & \multicolumn{2}{|c|}{$\begin{array}{c}15-16,18,21,25 \\
27\end{array}$} & \multirow[b]{2}{*}{$59.8 \%$} & \multirow[b]{2}{*}{$(453 / 758)$} \\
\hline & $17.4 \%$ & $(84 / 482)$ & $51.6 \%$ & $(276 / 535)$ & $69.6 \%$ & $(105 / 111)$ & & \\
\hline Celice & $89.4 \%$ & $(340 / 380)$ & $92.7 \%$ & $(164 / 177)$ & $94.7 \%$ & $(71 / 75)$ & $91.0 \%$ & $(575 / 632)$ \\
\hline Morten & $83.1 \%$ & $(103 / 124)$ & $83.6 \%$ & $(179 / 214)$ & $100 \%$ & $(4 / 4)$ & $83.6 \%$ & $(286 / 342)$ \\
\hline Inga & $54 \%$ & $(164 / 192)$ & $87 \%$ & $(90 / 104)$ & $90 \%$ & $(37 / 41)$ & $79.4 \%$ & $(332 / 418)$ \\
\hline Hedda & $24 \%$ & $(5 / 21)$ & $89 \%$ & $(86 / 98)$ & $91 \%$ & $(125 / 137)$ & $86.7 \%$ & $(320 / 369)$ \\
\hline Kimbo & $3.1 \%$ & $(3 / 97)$ & $8.7 \%$ & $(4 / 46)$ & $55.6 \%$ & $(10 / 18)$ & $10.6 \%$ & $(17 / 161)$ \\
\hline Klara & $94.1 \%$ & $(6 / 7)$ & $47.6 \%$ & $(10 / 21)$ & $96.8 \%$ & $(91 / 94)$ & $87.7 \%$ & $(107 / 122)$ \\
\hline total & $60.2 \%$ & $(675 / 1,121)$ & $80.5 \%$ & $(942 / 1,170)$ & $92.4 \%$ & $(475 / 514)$ & $74.6 \%$ & $(2,092 / 2,805)$ \\
\hline
\end{tabular}

Table A.3. Rate of SEN in ME across subject and group of recordings

\begin{tabular}{|c|c|c|c|c|c|c|c|c|}
\hline \multirow{3}{*}{$\begin{array}{l}\text { name } \\
\text { Lars-Lars }\end{array}$} & \multicolumn{6}{|c|}{ recordings } & \multicolumn{2}{|c|}{ total } \\
\hline & \multicolumn{2}{|c|}{$1-6$} & \multicolumn{2}{|c|}{$7-9,11-12,14$} & \multicolumn{2}{|c|}{$\begin{array}{c}15-16,18,21 \\
25,27\end{array}$} & & \\
\hline & $8.7 \%$ & $(2 / 23)$ & $69.2 \%$ & $(15 / 26)$ & $75 \%$ & $(6 / 8)$ & $45.6 \%$ & $(26 / 57)$ \\
\hline Celice & $72.3 \%$ & $(55 / 76)$ & $89.7 \%$ & $(35 / 39)$ & $100 \%$ & $(3 / 3)$ & $78.8 \%$ & $(93 / 118)$ \\
\hline Morten & $79.3 \%$ & $(23 / 29)$ & $95 \%$ & $(19 / 20)$ & $0 \%$ & $(0 / 1)$ & $84 \%$ & $(42 / 50)$ \\
\hline Inga & $75 \%$ & $(18 / 24)$ & $94.1 \%$ & $(16 / 17)$ & $50 \%$ & $(1 / 2)$ & $81.4 \%$ & $(35 / 43)$ \\
\hline Hedda & $72.7 \%$ & $(8 / 11)$ & $89.5 \%$ & $(17 / 19)$ & $100 \%$ & $(6 / 6)$ & $86.1 \%$ & $(31 / 36)$ \\
\hline Kimbo & $15.4 \%$ & $(4 / 26)$ & $25 \%$ & $(2 / 8)$ & $50 \%$ & $(1 / 2)$ & $19.4 \%$ & $(7 / 36)$ \\
\hline Klara & & & & & $86 \%$ & $(12 / 14)$ & & \\
\hline total & $58.2 \%$ & $(110 / 189)$ & $82.9 \%$ & (107/129) & $80.6 \%$ & $(29 / 36)$ & $69.5 \%$ & $(246 / 354)$ \\
\hline
\end{tabular}


Table A.4. Rate of SEN in YOU.SG across subject and group of recordings

\begin{tabular}{|c|c|c|c|c|c|c|c|c|}
\hline \multirow{3}{*}{$\begin{array}{l}\text { name } \\
\text { Lars-Lars }\end{array}$} & \multicolumn{6}{|c|}{ recordings } & \multicolumn{2}{|c|}{ total } \\
\hline & \multicolumn{2}{|c|}{$1-6$} & \multicolumn{2}{|c|}{$7-9,11-12$} & \multicolumn{2}{|c|}{$16,18,21,25,27$} & \multirow[b]{2}{*}{$65.9 \%$} & \multirow[b]{2}{*}{$(27 / 41)$} \\
\hline & $28.6 \%$ & $(4 / 14)$ & $82.6 \%$ & $(19 / 23)$ & $100 \%$ & $(4 / 4)$ & & \\
\hline Celice & $85.7 \%$ & $(18 / 21)$ & $93.8 \%$ & $(30 / 32)$ & $60 \%$ & $(6 / 10)$ & $85.7 \%$ & $(54 / 63)$ \\
\hline Morten & $96.6 \%$ & $(28 / 29)$ & $87.5 \%$ & $(7 / 8)$ & & & $94.6 \%$ & $(35 / 37)$ \\
\hline Inga & $25.9 \%$ & $(7 / 27)$ & $60 \%$ & $(3 / 5)$ & $100 \%$ & $(3 / 3)$ & $37.1 \%$ & $(13 / 35)$ \\
\hline Hedda & $50 \%$ & $(3 / 6)$ & $85.7 \%$ & $(6 / 7)$ & $75 \%$ & $(12 / 16)$ & $72.4 \%$ & $(21 / 29)$ \\
\hline Kimbo & $0 \%$ & $(0 / 1)$ & $11 \%$ & $(2 / 18)$ & $0 \%$ & $(0 / 1)$ & $10 \%$ & $(2 / 20)$ \\
\hline Klara & $0 \%$ & $(0 / 1)$ & $0 \%$ & $(0 / 7)$ & $83.3 \%$ & $(5 / 6)$ & $36.7 \%$ & $(5 / 14)$ \\
\hline total & $60.1 \%$ & $(60 / 99)$ & $67 \%$ & $(67 / 100)$ & $75 \%$ & $(30 / 40)$ & $65.7 \%$ & $(157 / 239)$ \\
\hline
\end{tabular}

Table A.5. Rate of SEN variant in YOU.PL across subject and group of recordings

\begin{tabular}{|c|c|c|c|c|c|c|c|c|}
\hline \multirow{3}{*}{$\begin{array}{l}\text { name } \\
\text { Lars-Lars }\end{array}$} & \multicolumn{6}{|c|}{ recordings } & \multicolumn{2}{|c|}{ total } \\
\hline & \multicolumn{2}{|c|}{$1-6$} & \multicolumn{2}{|c|}{$7-9,11-12,14$} & \multicolumn{2}{|c|}{$\begin{array}{c}15-16,18,21,25 \\
27\end{array}$} & \multirow[b]{2}{*}{$2.2 \%$} & \multirow[b]{2}{*}{$(2 / 84)$} \\
\hline & $0 \%$ & $(0 / 32)$ & $2.6 \%$ & $(1 / 30)$ & $4.5 \%$ & $(1 / 22)$ & & \\
\hline Celice & $16.7 \%$ & $(2 / 12)$ & $0 \%$ & $(0 / 4)$ & $66.7 \%$ & $(4 / 6)$ & $27.2 \%$ & $(6 / 22)$ \\
\hline Morten & $100 \%$ & $(1 / 1)$ & $44.4 \%$ & $(4 / 9)$ & $50 \%$ & $(1 / 2)$ & $50 \%$ & $(6 / 12)$ \\
\hline Inga & $33 \%$ & $(1 / 3)$ & $100 \%$ & $(0 / 3)$ & & & $16.7 \%$ & $(1 / 6)$ \\
\hline Hedda & $0 \%$ & $(0 / 2)$ & $0 \%$ & $(0 / 12)$ & $70 \%$ & $(7 / 10)$ & $29.2 \%$ & $(7 / 24)$ \\
\hline Kimbo & $0 \%$ & $(0 / 2)$ & $12.5 \%$ & $(1 / 8)$ & $0 \%$ & $(0 / 4)$ & $7.1 \%$ & $(1 / 14)$ \\
\hline Klara & $100 \%$ & $(1 / 1)$ & $0 \%$ & $(0 / 7)$ & $100 \%$ & $(2 / 2)$ & $30 \%$ & $(3 / 10)$ \\
\hline total & $9.4 \%$ & $(5 / 53)$ & $7.3 \%$ & $(6 / 82)$ & $32.6 \%$ & $(15 / 46)$ & $14.4 \%$ & $(26 / 181)$ \\
\hline
\end{tabular}


Table A.6. Rate of SEN in BE.PL across subject and group of recordings

\begin{tabular}{|c|c|c|c|c|c|c|c|c|}
\hline \multirow{3}{*}{$\begin{array}{l}\text { name } \\
\text { Lars-Lars }\end{array}$} & \multicolumn{6}{|c|}{ recordings } & \multicolumn{2}{|c|}{ total } \\
\hline & \multicolumn{2}{|c|}{$1-6$} & \multicolumn{2}{|c|}{$7-9,11-12,14$} & \multicolumn{2}{|c|}{$15-16,21,25,27$} & \multirow[b]{2}{*}{$12.5 \%$} & \multirow[b]{2}{*}{$(19 / 152)$} \\
\hline & $7.1 \%$ & $(2 / 28)$ & $6.7 \%$ & $(6 / 89)$ & $31.4 \%$ & $(11 / 35)$ & & \\
\hline Celice & $15.1 \%$ & $(8 / 53)$ & $31.6 \%$ & $(13 / 19)$ & $40 \%$ & $(6 / 15)$ & $23 \%$ & $(20 / 87)$ \\
\hline Morten & $13.3 \%$ & $(10 / 75)$ & $27.1 \%$ & $(26 / 96)$ & $25 \%$ & $(1 / 4)$ & $21.1 \%$ & $(37 / 175)$ \\
\hline Inga & $55.8 \%$ & $(24 / 43)$ & $22.2 \%$ & $(8 / 36)$ & $50 \%$ & $(6 / 12)$ & $41.8 \%$ & $(38 / 91)$ \\
\hline Hedda & $13.6 \%$ & $(9 / 66)$ & $18.1 \%$ & $(13 / 72)$ & $32.1 \%$ & $(9 / 28)$ & $18.7 \%$ & $(31 / 166)$ \\
\hline Kimbo & $7 \%$ & $(6 / 86)$ & $16 \%$ & $(4 / 25)$ & $16.7 \%$ & $(1 / 6)$ & $7 \%$ & $(7 / 95)$ \\
\hline Klara & $0 \%$ & $(0 / 15)$ & $30.8 \%$ & $(4 / 13)$ & $25 \%$ & $(3 / 12)$ & $9.4 \%$ & $(11 / 117)$ \\
\hline total & $16.1 \%$ & $(59 / 366)$ & $19.4 \%$ & $(68 / 351)$ & $33 \%$ & $(37 / 112)$ & $18.7 \%$ & $(155 / 829)$ \\
\hline
\end{tabular}

Cite this article: Strand B-MS (2020). Morphological variation and development in a Northern Norwegian role play register. Nordic Journal of Linguistics 43, 289-321. https://doi.org/10.1017/S0332586520000219 